\title{
CLIȘEE DIN SCENARIUL DEZBATERILOR PRIVIND STATUTUL ȘI CONȚINUTUL OREI DE RELIGIE ÎN SISTEMUL NAȚIONAL DE EDUCAȚIE AL GRECIEI
}

\section{Ion Marian Croitoru*}

\begin{abstract}
The status and the content of the Religion Class holds a special place in the debates and polemics of the Greek society, especially lately, when the problem emerged is the replacement of the current Curriculum by a new one meant to turn the Religion Class into a class of History of Religions or even Religious Syncretism. In the Greek national education system, the Religion Class is part of the "general education core" and is obligatory, being exempted from it only the pupils of a different religion, the heterodox and those without religion, who invoke reasons of religious conscience. According to the current Curriculum, the religion textbooks' priority is the teaching of the knowledge related to the local Orthodox tradition and teaching, which would be closer to the concept of "religious literacy", as developed by Andrew Wright, whereas the new Curriculum pursues the application of Robert Jackson's concept, namely the realization of a "liberal religious education", by trying to find common points of all the religions and create a particular religious faith, thus cultivating rather an "interreligious literacy". To highlight the concepts concerning the content of the Religion Class, and also certain events and positions taken by the Church, with the contribution of the hierarchy and of the religion teachers, to which one can add the support of numerous Greek intellectuals and politicians, the structure of the research axis in this study includes: the presentation of the content and status of the Religion Class in Greece; the description of the struggle of the religion teachers' unions; the information of the Romanian society about the efforts made in the Greek society in order to maintain the status of the Religion Class and its content based on the Orthodox Christian tradition; the delineation of certain aspects concerning the celebration of the spiritual patrons of Education and Letters in Greece (the Three Holy Hierarchs: Basil the Great, Gregory the Theologian and John Chrysostom).
\end{abstract}

Keywords: Religion Class, religious education, religious literacy, liberal religious education, Orthodoxy, Church, religious syncretism, Curriculum, Greece.

\footnotetext{
* PhD, Assistant Professor, Faculty of Othodox Theology and Education Sciences, at "Valahia" University, Târgovişte, Romania.
} 


\section{Introducere}

$\mathrm{Cu}$ ocazia participării la Seminarul Internațional de Medicină și Teologie, ediția a XIV-a, organizat la Bistrița, în perioada 11-12 mai 2015, de către Arhiepiscopia Ortodoxă Română a Vadului, Feleacului şi Clujului, împreună cu Facultatea de Teologie Ortodoxă a Universităţii Babeş Bolyai din Cluj-Napoca și alte instituții, am expus un studiu despre ora de religie în învățământul național al Greciei, prezentând:

1) repere privind statutul orei de religie în cadrul învățământului de stat din Grecia;

2) reacția societății grecești la zvonurile despre ora de religie;

3) patronii spirituali ai învățământului din Grecia. Având în vedere actualitatea subiectului, atât pentru Grecia, cât și pentru România, voi relua în referatul consacrat celui de al XV-lea Simpozion Internațional de Ştiinţă, Teologie şi Arte (ISSTA 2016), organizat la Alba Iulia, în perioada 9-11 mai 2016, unele teme din studiul menționat, în vederea introducerii în varietatea subiectului și, implicit, a actualizării lor, la care voi adăuga, în limita timpului și a spațiului rezervat susținerii și publicării acestui referat, argumente și poziții pe care Biserica Ortodoxă din Grecia, prin aportul ierarhilor, al profesorilor de religie și al unor intelectuali mireni, le susține în dezbaterile purtate cu Ministerul Educației, Cercetării și Cultelor din această țară, dar și cu alți factori decizionali, referitor la statutul și conţinutul orei de religie.

\section{Conținutul și statutul orei de religie în Grecia}

În ciuda dezbaterilor duse în ultima vreme de către unii care doresc să schimbe conținutul orei de religie în sistemul național educațional din Grecia, se constată că această disciplină și-a păstrat conţinutul învăţăturii creştine ortodoxe, fiind predată atât la ciclul

\footnotetext{
${ }^{1}$ Intitulat Ora de religie sau ora de educație creștină? Câteva referințe din experiența învățământului național al Greciei, dat spre publicare în volumul cu lucrările respectivului Seminar.
} 
primar, care este de 6 ani, precum și la ciclul gimnazial, care durează 3 ani, și liceal, care se întinde, de asemenea, pe 3 ani.

Pentru anul şcolar 2015-2016, cât priveşte obligativitatea şi scutirile de la ora de religie, precum şi conţinutul acestei ore, a fost

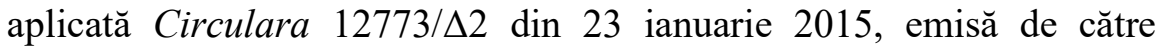
Ministerul Educaţiei, Cercetării și Cultelor, având ca temă „reglarea temelor şcolare" privind ora de religie ${ }^{2}$. Din cuprinsul ei se desprind următoarele:

1) ora de religie „este obligatorie pentru toţi elevii”, citându-se, în acest sens, şi articolul care întăreşte acest fapt din Constituţia ${ }^{3}$ Greciei (art. 16, alin. 2);

2) se predă în unităţile şcolare din Ciclul primar și cel secundar, adică la Şcoala Primară (Ciclul primar), Gimnaziu şi Liceu (Ciclul secundar);

3) conţinutul orei de religie, după cum se poate constata din cele exprimate, este creştin ortodox, din moment ce sunt scutiţi de la această oră doar „elevii necreştini ortodocşi, adică cei de altă religie, eterodocşii şi cei fără de religie, care invocă motive de conştiinţă religioasă";

4) directorul unităţii şcolare, împreună cu Consiliul cadrelor didactice din unitatea respectivă, hotărăsc, după caz, activităţile sau orele pe care le vor urma, în mod obligatoriu, elevii scutiţi;

5) valabilitatea unei scutiri este anuală, de la 1 septembrie, adică de la începutul anului școlar, până la 20 septembrie, în anul calendaristic următor sau de încheiere al aceluiași an școlar, şi se înnoieşte în fiecare an şcolar, urmărindu-se aceeaşi procedură;

6) prin emiterea acestei Circulare încetează să mai fie valabile Circularele anterioare, referitoare la aceeaşi temă $(91109 / \Gamma 2 / 10.07$.

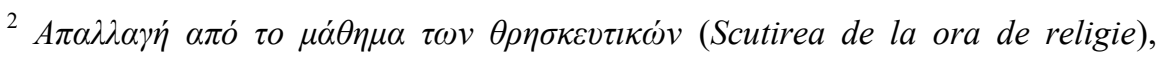

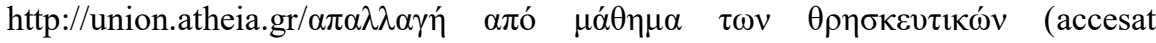
14.04.2016).

${ }^{3}$ Constituţia Greciei, votată la 11 iunie 1975, a fost revizuită în anii 1986, 2001 şi 2008. 
2008; 104071 / Г2 / 04. 08. 2008; Ф12/ 977 / 109744 / Г1 / 26.08. 2008 şi $133099 / \Gamma 2 / 19.09 .2013)^{4}$.

De menționat că ora de religie face parte din „trunchiul de bază al disciplinelor de educaţie generală" ${ }^{, 5}$, precum și faptul că abia în anul 2008 s-a pus problema pentru cei ce nu doresc să frecventeze ora de religie, admițându-se atunci ca aceştia să facă cerere de scutire, dar să dovedească motivul sau motivele pentru care se solicită acest lucru.

În Constituţia Greciei se recunoaşte, prin articolul 3, că religia dominantă este cea a „Bisericii Ortodoxe Răsăritene a lui Hristos”, adică cea ,creştină ortodoxă”, şi, prin urmare, admite un statut special pentru Biserica Ortodoxă a Greciei, recunoscându-i organizarea internă, supunerea faţă de Patriarhia Ecumenică şi canoanele pe care le ţine. În articolul 16, aliniatul 2, aceeaşi Constituţie impune, printre altele, dezvoltarea conştiinţei religioase a elevilor prin educaţie, sub forma orei de religie.

Organul abilitat pentru redactarea şi editarea manualelor şcolare este Ministerul Educaţiei care, prin intermediul Institutului de Politică

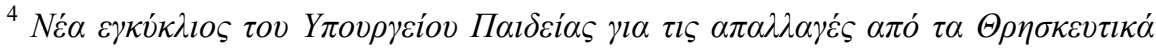
(Noua circulară a Ministerului Educației pentru scutirile de la ora de religie), http://www.petheol.gr/nea/ekpaideutika-

ea/neaenkykliostouypourgeioupaideiasgiatisapallagesapotathreskeutika (accesat 08.05.2015). La începutul anului școlar 2015-2016, s-a înregistrat și tendința unor organisme [vezi iniţiativa Federației Profesorilor din Învățământul Secundar

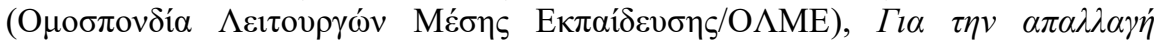

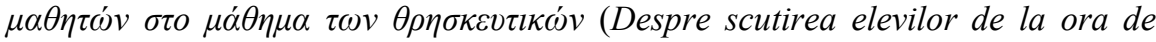
religie), http://olme-attik.att.sch.gr/new/wpcontent/uploads/2015/09/apallagesthriskeutika25092015.pdf (accesat 15.04.2016)]

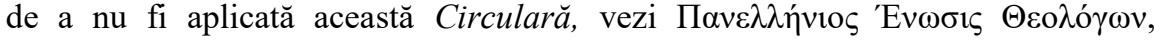

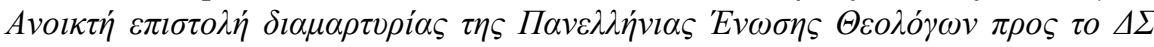

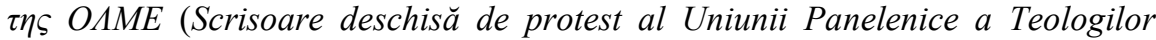
către Consiliul Administrativ al OAME), http://www.petheol.gr/nea/anoikteepistolediamartyriastespanelleniasenosestheolo gonprostodstesolme (accesat 15.04.2016). OAME este acronimul indicat mai sus, chiar în această notă.

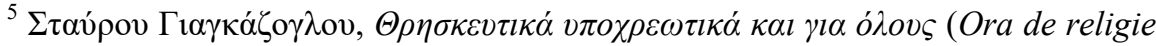
obligatorie și pentru toți), http://www.kairosnet.gr/joomla/index.php/2010-12-1321-49-14/73--1-r.html (accesat 09.05.2015). 


\section{$15^{\text {th }}$ International Simposium on Science, Theology and Arts}

Educaţională, denumit și Institutul Pedagogic, se adresează specialiştilor (conform Legii 1566 / 1985, articolul 24), fie pentru a le cere sfatul, fie pentru a le încredinţa redactarea materialului didactic, pe care îl aprobă, în cele din urmă, Ministerul. Totuşi, conţinutul manualelor de religie nu poate să fie aprobat fără acordul Bisericii care, prin lege, colaborează cu statul în toate problemele de interes comun, după cum sunt cele ale educaţiei creştine a tineretului (Legea 590/1977, art. 2), iar Sfântul Sinod Permanent al Bisericii are dreptul să urmărească „conţinutul ortodox al manualelor şcolare pentru ora de religie" (Legea 590/1977, art. 9, alin. 1).

De altfel, atât Constituţia Greciei (art. 16, alin. 2), cât şi Legea 590/1977 nu îngăduie în niciun caz ca dogmele şi învăţătura religiei ce este recunoscută ca dominantă, calitate revenită Bisericii Ortodoxe, să fie falsificate de către vreo autoritate a statului. În consecinţă, dacă se constată „tulburarea Bisericii Ortodoxe printr-o învăţătură străină sau altă intervenţie în detrimentul ei”, Sfântul Sinod Permanent are dreptul să ceară sprijinul Autorităţilor (Legea 590/1977, art. 9, alin. 1). Prin urmare, Ministerul Educaţiei nu are dreptul să stabilească unilateral materialul didactic al orei de religie, ci doar în colaborare şi cu încuviinţarea Bisericii ${ }^{6}$.

Această realitate este întâlnită nu doar în Grecia, ci, așa cum se arată în literatura de specialitate, și în ţări ca Germania, Irlanda, Austria, Elveţia, Olanda, Portugalia, Belgia, Cipru, Malta etc. ${ }^{7}$ De

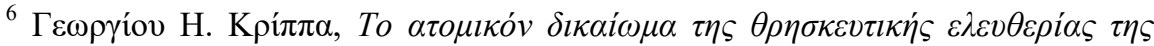

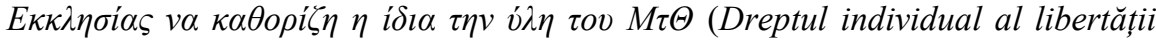
Bisericii de a stabili ea însăși materia pentru ora de religie), http://www.petheol.gr/arthra/to-mathema-ton-

threskeutikon/toatomikondikaiomatesthreskeutikeseleutheriastesekklesiasnakathor izeeidiatenyletoumtth (accesat 09.05.2015). $M \tau \Theta$ este acronimul pentru $M \dot{\alpha} \theta \eta \mu \alpha$ $\Theta \rho \eta \sigma \kappa \varepsilon v \tau \iota \kappa \omega ́ v$, însemnând ora de religie.

7 În aceeaşi literatură se specifică şi faptul că aparte este cazul Franţei care, deşi se consideră un stat laic, stipulându-se despărţirea dintre Stat şi Biserică, finanţează, totuşi, Biserica Romano-catolică şi îngăduie, prin susţinerea financiară de la Stat, predarea orelor de religie în Alsacia şi Lorena, iar în restul teritoriului, cât priveşte şcolile de stat, se prevede (prin articolul L141-3 al Codului de Educaţie) o oră liberă pe săptămână în programul şcolar, când elevii au voie să meargă în biserici, 
pildă, în zonele unde religia dominantă este credinţa romano-catolică, statul respectiv a încheiat un Concordat cu Vaticanul, prin care îşi asumă obligaţia să asigure predarea orei de religie conform învăţăturii Bisericii Romano-catolice. În ţările protestante (Anglia, Danemarca, Scandinavia), Bisericile respective sunt recunoscute ca oficiale şi au drepturi cât priveşte conţinutul orei de religie. Situaţia din aceste ţări, dar şi din Grecia, este confirmată de Recomandarea Consiliului European (1720/2005), cu titlul Educaţie şi religie (Education et Religion), în care sunt stipulate, printre altele:

a) democraţia şi religia nu sunt contrare (alin. 5);

b) guvernele trebuie să sprijine predarea orei de religie (alin. 6);

c) statele europene care au o religie oficială au dreptul să-i recunoască o poziţie privilegiată (alin. 9);

d) Adunarea Parlamentară recomandă, de asemenea, Comisiei de minişstri să întărească statele membre în a supraveghea predarea religiei la Ciclurile I şi II din sistemul naţional de educaţie (alin. 14); $14.5)^{8}$.

e) profesorii de religie trebuie să aibă o pregătire specială (alin.

Explicabil devine, aşadar, motivul pentru care conţinutul orei de religie are în Grecia, dar şi în statele menţionate mai sus, o formă catehetică, deci confesională, şi nu de istorie a religiilor. În faţa acestui fapt, nu înseamnă că Grecia a fost lipsită de vocile acelora care au cerut şi cer transformarea orei de religie într-una de istorie a religiilor sau de orientare gnoseologică, voci venite chiar din partea unei mici grupări de teologi, adică profesori de religie, sau a unor oameni politici ${ }^{9}$.

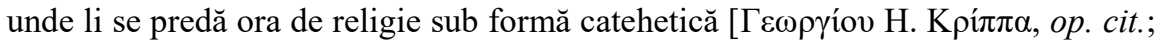
despre cazul Franţei, dar şi al altor state europene, vezi şi Ion Croitoru, Heliana Munteanu, The Moral-religious Education - A Support of Self-conscience Training, în „Procedia - Social and Behavioral Journal”, 116 (2014), p. 21552163].

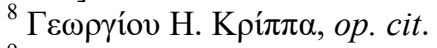

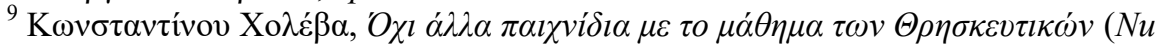
alte jocuri cu ora de religie), http://www.petheol.gr/nea/ekpaideutikanea/konstantinoscholebasochiallapaichnidiametomathematonthreskeutikon (accesat 15.04.2016). 
Într-un Răspuns (184728/Ф1/168732/16-11-2015) al ministrului Educației, Nicolae Fílis (Nıкó $\alpha$ os $\Phi i ́ \lambda \eta \varsigma)$, la Petiția (ПАВ 109/22-10-

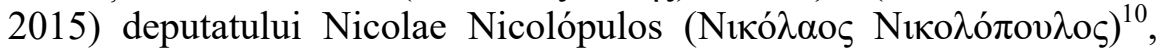
președintele Partidului Creștin-Democrat din Grecia, privind statutul orei de religie la Ciclul secundar de educație, adică la Gimnaziu și Liceu, se precizează, printre altele, că pentru anul școlar 2015-2016: la fiecare dintre cele trei clase de Gimnaziu se vor preda 2 ore de religie, săptămânal; la primele două clase de Liceu general se vor preda 2 ore de religie, săptămânal, iar la ultima clasă de Liceu general se va preda o oră de religie pe săptămână; scutirea elevilor se va face conform Circularei 12773/د2/23.01.2015, amintită mai sus; "din motive istorice, ora de religie are în țara noastră, adică în Grecia, un caracter confesional", socotindu-se, însă, acest lucru ca fiind un ,anacronism pe care îl percep și ierarhi şi teologi iluminați”. De altfel, nu se evită recomandarea în acest Răspuns că ,este necesară reformularea orei de religie, încât să devină o oră de istorie a religiilor, de cunoaștere a religiilor, cu prezentarea deosebită a rolului civilizator al Ortodoxiei în țara noastră $" 11$.

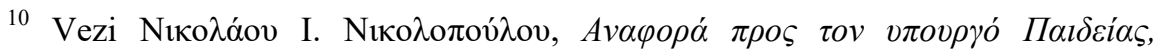

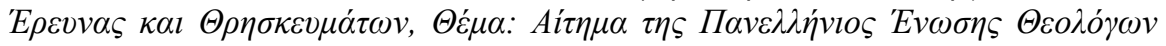

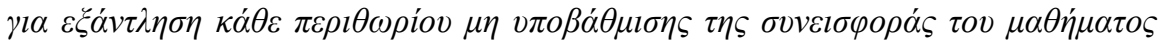

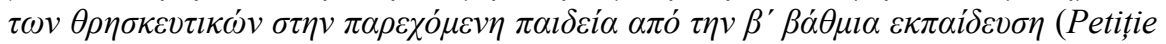
către ministrul Educației, Cercetării și Cultelor, Subiectul: Cerere a Uniunii Panelenice a Teologilor pentru epuizarea oricărei limite privind nedeclasarea contribuției orei de religie la educația predată în Învățământul de gradul al IIlea), http://www.hellenicparliament.gr/UserFiles/c0d5184d-7550-4265-8e 0b078e1bc7375a/9358236.pdf (14.04.2016).

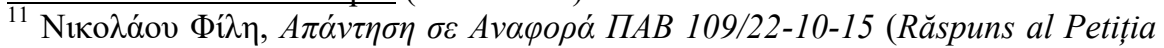
ПАВ 109/22-10-15), http://www.hellenicparliament.gr/UserFiles/67715b2c-ec814f0c-ad6a-476a34d732bd/9391198.pdf (14.04.2016). Cât privește cele șase clase de la ciclul primar sau Școala primară, se predau două ore săptămânal, excepție făcând primele două clase, la care nu se predă nicio oră de religie, vezi http://edu.klimaka.gr/leitoyrgia-sxoleivn/dimotiko/726-wrologio-programmadhmotiko-scholeio.html (accesat 15.04.2016). 


\section{Lupta sindicală}

În vederea menținerii statutului orei de religie, dar și pentru apărarea drepturilor profesorilor de religie, în Grecia activează două Asociaţii sau Corporaţii sindicaliste ale cadrelor didactice de resort.

Prima dintre ele și cea mai cunoscută este Uniunea Panelenică $a$

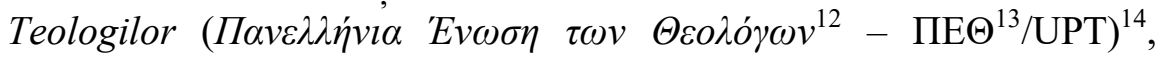
considerată a fi o grupare tradiţionalistă, însă, după unii, chiar conservatoristă. $\mathrm{Cu}$ toate acestea, Uniunea Panelenică a Teologilor are caracterul unei asociaţii ştiinţifice şi sindicaliste, fiind înfiinţată în 1950 și recunoscută legat în 1951, având atunci titlul de Uniunea Teologilor Greci. În 1961, titulatura se schimbă în Uniunea Panelenică a Teologilor, păstrată până în timpul actual, iar din această Uniune face parte cel mai mare mare număr al profesorilor de religie, denumiți cu termenul de „teologi” în societatea grecească. De menționat că $\Pi E \Theta / U P T-u l$ are şi o revistă trimestrială, Kolvwvía (Comuniune) ${ }^{15}$, în care sunt tipărite diferite teme şi cercetări privind statutul orei de religie, conţinutul manualelor etc.

Cea de a doua corporaţie este Asociaţia Teologică Panelenică

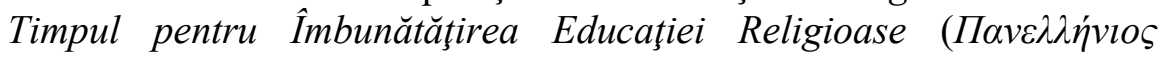

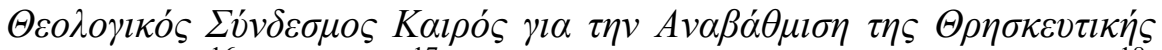
$\left.E \kappa \pi \alpha i \delta \varepsilon v \sigma \eta \varsigma^{16}-\Pi \Theta \Sigma \mathrm{K}^{17} / \mathrm{ATPT}\right)$, care cultivă un duh progresist ${ }^{18}$. Această Asociaţie a fost fondată în 2010, ca un grup de o altă orientare faţă de Uniunea Panelenică a Teologilor, şi are ca ţintă, după cum reiese din titulatură, imbunătăţirea educaţiei religioase.

${ }^{12}$ A se citi Panellínia Énosi ton Teológon. De luat în consideraţie că am marcat şi accentul, acolo unde este cazul, pentru intonaţia corectă.

${ }^{13}$ A se citit PET.

${ }_{15}^{14}$ Pentru adresa web vezi http://www.petheol.gr.

${ }^{15}$ A se citi Chinonía.

16 A se citi Panellínios Teologhicós Sýndesmos Cherós ia tin Anavátmisi tis Trischeftikis Ecpédefsis.

${ }^{17}$ A se citi PTSC.

${ }^{18}$ Pentru adresa web vezi http://www.kairosnet.gr. 
Referitor la conţinutul orei de religie, atât Asociaţia Teologică Panelenică Timpul, cât şi Uniunea Panelenică a Teologilor au o poziţie comună, şi anume, să fie axat pe tradiţia ortodoxă specifică societăţii greceşti, dar, totuşi, cu o mare diferenţă. Asociaţia Teologică Panelenică Timpul doreşte ca ora de religie să aibă mai mult un conţinut gnoseologic, pe când Uniunea Panelenică a Teologilor susţine conţinutul confesional al credinţei ortodoxe $\mathrm{e}^{19}$.

Circulara 12773/A2/23.01.2015, menţionată mai sus, este rezultatul unor lungi şi acerbe dezbateri, susţinute mai ales de către Uniunea Panelenică a Teologilor. Un precedent 1-a constituit Hotărârea 115/2012 a Curţii de apel din Haniá (Creta), eliberată în urma împuternicirii venite din partea Consiliului de Stat al Greciei, privind motivele scutirii elevilor de la orele de religie, care Hotărâre a fost categorică în favoarea obligativităţii acestei ore:

„,nu se concepe vreo scutire de la ora de religie pentru un elev creştin ortodox din motive de conştiinţă religioasă. Elevii fără de religie, cei de alte religii (de pildă, musulmanii) şi cei eterodocşi (de pildă, protestanţii) au dreptul de scutire de la oră numai dacă există pentru persoana lor motive de conştiință religioasă, pe care sunt datori să le invoce ei înşişi sau părinţii lor"20.

În acel timp se formaseră cinci concepte referitoare la conţinutul orei de religie:

1) „oră confesională deschisă”, cu un conţinut creştin ortodox, susţinut de către Uniunea Panelenică a Teologilor, adică de către

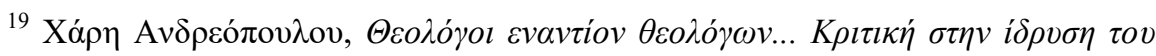

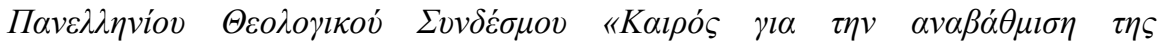

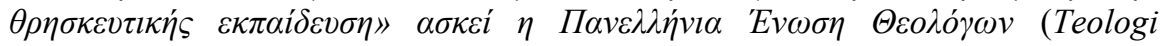
împotriva teologilor... Critică la înființarea Asociației Teologice Panelenice «Timpul pentru îmbunătățirea educației religioase» exercită Uniunea Panelenică a Teologilor), http://www.amen.gr/article/theologoi-enantion-theologwn (accesat 09.05.2015).

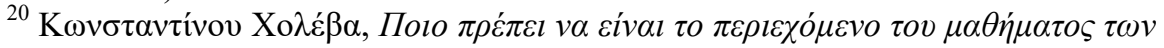

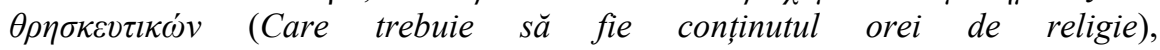
http://www.antibaro.gr/article/11379 (accesat 09.05.2015). 
majoritatea profesorilor de religie din Grecia, cărora li s-a alăturat şi Uniunea Pancipriotă a Teologilor Greci, dat fiind faptul că în Cipru se predă, pentru Gimnaziu şi Liceu, după manualele elaborate în Grecia. Este numită ,ora deschisă”, pentru că nu are tonul catehetic auster, ca în vechime, şi reprezintă tendinţa cea mai susţinută;

2) „oră culturală a religiilor”, având ca titlu general „,moştenirea creştină ortodoxă”, fiind o tendinţă singulară;

3) conceptul, de asemenea, singular, ca ora de religie să nu aibă nici „,caracterul clasic catehetic (sau confesional)”, dar nici în mod exclusiv să fie o oră de orientare gnoseologică sau culturală, ci să se bazeze pe ,valorile duhovnicești diacronice ale Bibliei, care, de altfel, acoperă, într-o mare măsură, cele trei religii monoteiste, care au rădăcini în Europa" ${ }^{, 21}$;

4) „oră gnoseologică interreligioasă”, care nu se mai bazează pe credinţa şi tradiţia ortodoxă, tendinţă respinsă, însă, chiar de legislaţia Greciei în vigoare;

5) „oră în mod pur religioasă”, susţinută de către anumite partide de stânga, tendinţă considerată şi ea în afara cadrului legislativ al Greciei $^{22}$.

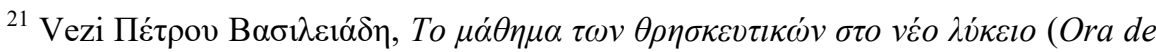
religie in noul liceu), http://www.amen.gr/article/to-mathima-twn-thriskeutikwn-

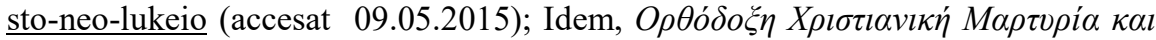
$\Theta \rho \eta \sigma \kappa \varepsilon v \tau \iota \kappa \eta ் ~ E \kappa \pi \alpha i ́ \delta \varepsilon v \sigma \eta$ (Mărturia creștină ortodoxă și Educația religioasă), http://www.amen.gr/article/orthodoksi-xristianiki-marturia-kai-thriskeutikiekpaideusi (accesat 09.05.2015)

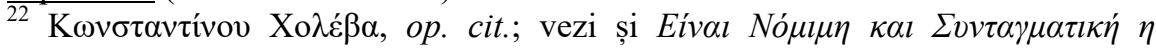

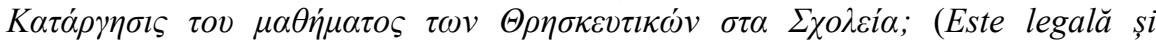

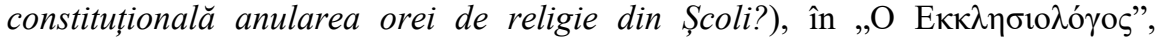
31.10.2015, p. 13. 


\section{Eforturile depuse în societatea greacă pentru menținerea statutului orei de religie, precum și a conținutului ei bazat pe tradiția creștină ortodoxă}

Dacă în studiul menționat la începutul acestui referat am pus accentul pe reacția oamenilor politici din Grecia în favoarea orei de religie, motivând menținerea ei în școli cu conținutul învățăturii ortodoxe, deci cu păstrarea caracterului confesional, avându-se în vedere strânsa legătură dintre politicieni şi ierarhii greci, dar şi conexiunile celor dintâi cu preoţii şi duhovnicii de la mănăstiri şi parohii, dar şi cu alegătorii lor, în paginile ce urmează voi arăta câteva dintre argumentele și pozițiile Bisericii, prin aportul profesorilor de religie, conjugat cu cel al clerului și al profesorilor de teologie, privind problematica orei de religie în societatea greacă.

Din documentele consultate, în cea mai mare parte a lor fiind date publicități pe diferite site-uri, reiese că de la începutul anului școlar 2015-2016 și până în momentul de față (aprilie-mai 2016) a fost dezbătut permanent conținutul orei de religie, adică între a se păstra caracterul confesional sau a se transforma într-o oră de istorie a religiilor sau chiar de sincretism religios, precum și statutul ei obligatoriu sau facultativ.

Disputa nu este nouă în societatea greacă, iar reacțiile au fost pe măsură. De pildă, la Consfătuirea anuală dintre Sfântul Sinod al Bisericii Ortodoxe şi profesorii Facultăţilor de Teologie din Grecia, eveniment ținut în ziua sau în preajma cinstirii Sfântului Fotie cel Mare (6 februarie), în mănăstirea Pendéli de lângă Atena, discuțiile din anul 2014 au fost asupra conţinutului orei de religie. $\mathrm{Cu}$ ocazia acestui eveniment, Uniunea Panelinică a Teologilor aducea acuzaţii organizaţiei Asociaţia Teologică Panelenică Timpul pentru acţiunile ei $\operatorname{progresiste~}^{23} . \mathrm{Nu}$ înseamnă că aceste două Asociaţii sunt mereu în

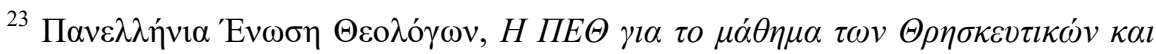

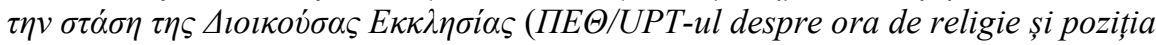
Bisericii care administrează), http://www.amen.gr/article/i-peth-gia-to-mathima-

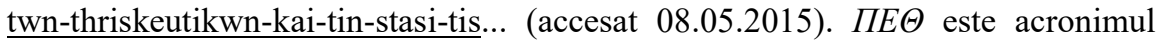

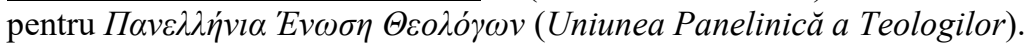


conflict, ci fac şi front comun, cum a fost cazul întâlnirii de la mănăstirea Pendéli din aprilie 2011.

$\mathrm{Cu}$ această ocazie, s-a discutat propunerea Ministerului Educaţiei de a nu fi obligatorie ora de religie la ultimul an de liceu, însă, propunerea Sfântului Sinod, precum şi a Facultăţilor de Teologie şi a Uniunilor şi Asociaţiilor teologice a fost unanimă şi se susţinea menţinerea obligativităţii orei de religie pentru toate ciclurile de educaţie $^{24}$. În 2011, se începuse un Program pilon numit Noua şcoală, în care ora de religie se dorea să fie cu un conţinut general de educaţie religioasă şi nu catehetic. Uniunea Panelenică a Teologilor s-a opus acestui Program pilon, iar în mai 2012 a avut loc o întâlnire cu responsabilii Programului. Din partea ierarhiei, în acel timp, s-au proclamat, totuşi, în favoarea Programului pilon, cu referate susţinute, mitropoliții Antim de Alexandrupolis şi Hrisostom de Messinia ${ }^{25}$.

În zilele de 12 și 13 ianuarie 2016, Sfântul Sinod Permanent al Bisericii Greciei ${ }^{26}$ a analizat subiectul privind conținutul orei de religie în Învățământul secundar (Gimnaziu și Liceu). La prima ședință (12.01.2016), pe lângă președintele și membrii Sfântului Sinod Permanent, au fost prezenți decanii și președinții Departamentelor celor două Facultăți de Teologie din Atena și Tesalonic, președinți celor două Asociații ale profesorilor de religie, $\Pi E \Theta^{27} / \mathrm{UPT}$ și $\Pi \Theta \Sigma \mathrm{K}^{28} / \mathrm{ATPT}$, iar mitropolitul Ierotei de Nafpáctos $^{29}$ și Sfântul

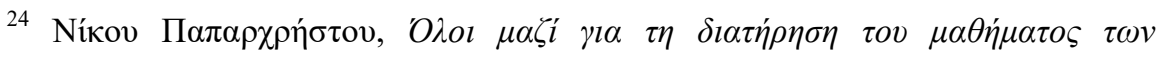

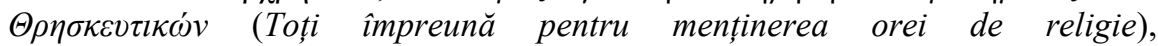
http://www.amen.gr/article/oloi-mazi-gia-ti-diatirisi-tou-mathimatos-twnthriskeutikwn (accesat 09.05.2015).

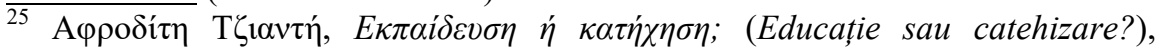
http://users.sch.gr/gkapetanak/autosch/joomla15/index.php/11-news-events/50ekpaidefsi-i-katixisi (accesat 09.05.2015).

${ }^{26}$ Sfântul Sinod Permanent este alcătuit din 13 ierarhi titulari, dintre care unul este Întâistătătorul Bisericii Greciei, care are și funcția de președinte, iar ceilalți $12 \mathrm{au}$ calitatea de membri ai Sfântului Sinod Permanent doar de-a lungul unui an bisericesc, după care sunt înlocuiți cu alți ierarhi.

${ }^{27}$ A se citi PET.

${ }^{28}$ A se citi PTSC.

${ }^{29}$ Localitate cunoscută şi cu numele latinizat de Naupactus. 


\section{$15^{\text {th }}$ International Simposium on Science, Theology and Arts}

Vlasie, membru în acest Sfântul Sinod Permanent pentru anul

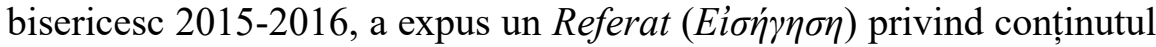
orei de religie, Programele Analitice de Studii (cea în vigoare și noua Programă propusă) și modalitatea de îmbunătățire și îmbogățire a Programei de Studii ${ }^{30}$, care se află în uz ${ }^{31}$.

La cea de a doua ședință (13.01.2016), Sfântul Sinod Permanent a ajuns, în urma discuțiilor pe baza Referatului mitropolitului Ierotei, la mai multe concluzii, formulate într-un document, pe care, în cele ce urmează, le prezint pe scurt:

1) manualele orei de religie sunt în mod eronat caracterizate ca fiind „,catehetice și confesionale”; ele au un caracter „gnoseologic și cultural, cu referință de istoria religiilor; de pildă, manualele pentru Liceu au materie despre alte religii și confesiuni, cu ocazii de problematizare despre dimensiunile religioase și morale privind probleme contemporane;

2) „faptul că în manualul de astăzi are prioritate predarea cunoștințelor în jurul tradiției religioase ortodoxe a locului”, nu îl transformă din „oră de formare religioasă într-o procedură de prozelitism al elevilor neortodocși sau de cateheză a elevilor ortodocși, nici nu se adresează cu exclusivitate ultimilor"; afirmațiile despre așazisul caracter confesional al orei de religie „pleacă de la avertizarea negativă despre disciplina însăși și rolul educatorilor, adică al profesorilor de religie, [fiind ei] oameni de știință, ca purtători ai așanumitului misionarism în școala greacă; ,de altfel, caracterul obiectiv al orei de religie nu este atins de expunerea, în mod prioritar, a tradiției creștine ortodoxe", de vreme ce, în mod necesar, materia de predare trebuie să aibă în vedere contextul local, istoric, religios și al majorității

30 „Programa Analitică” și „Programa de Studii” reprezintă ceea ce în literatura de specialitate se numește „Curriculum”. Cât privește literatura greacă de specialitate, diferența dintre cele două Programe constă în metodele didactice folosite.

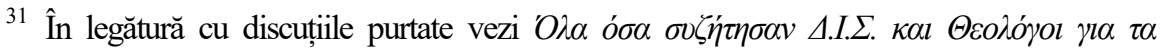

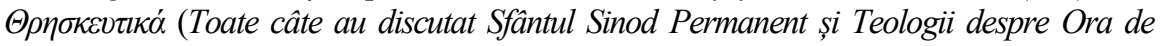

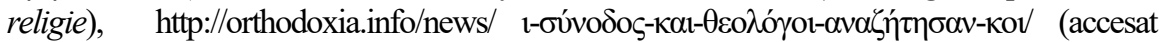
16.04.2016). 
populației, pe care îl exprimă ordinea școlară grecească, precum şi scopul integrării firești a elevului în societatea greacă, care, în majoritatea ei, îmbrățișează „,dogma creștină ortodoxă”;

3) hotărâri vechi și recente, eliberate de instituții și complexe de judecată, care interpretează Constituția, se pronunță în unanimitate în favoarea obligativității orei de religie, având ca bază principală „tradiția creștină ortodoxă”, precum și scutirea de la oră pentru cei ce nu sunt creștini ortodocși; în mod paralel, după cum a explicat Curtea Europeană a Drepturilor Omului, ,se cuvine ca disciplina de religie, după cum și toate disciplinele școlare, să fie dominate de principiile obiectivităţii și ale pluralismului, dar aceste principii nu sunt încălcate pentru simplul fapt că ora de religie se referă, în primul rând, la tradiția religioasă dominantă a propriului stat, satisfăcând și dorința părinților elevilor";

4) pentru menținerea aceleași metodologii a Programei de Studii în vigoare cât privește organizarea istorică a materiei, ,este posibil să fie adăugiri, care lărgesc domeniul de istoria religiilor, ideologic şi cultural al materiei, cu scopul de creștere a valorii de formare și a contribuției lui la educarea tinerilor"; însă, propunerea este ca aceste adăugiri să fie puse la sfârșitul fiecărui manual, cu referire la Învățământul secundar (Gimnaziu și Liceu), ,astfel încât elevii, a căror majoritate aparține Bisericii Ortodoxe, dar și câți elevi neortodocși doresc să dobândească cunoștințe globale despre tradiția religioasă și culturală a locului nostru, să aibă o imagine bine conturată";

5) într-o epocă în care sunt întărite păreri fundamentaliste ale altor religii, tendințe antisociale ale unor fenomene extreme religioase și secte periculoase, ,învățătura Teologiei Ortodoxe, care se distinge pentru iubirea, toleranța, dispoziția irenică și este scutită de fundamentalisme și forme de rasism, va ajuta în mod suficient și la coeziunea socială"; prin urmare, disciplinele școlare, parte integrantă fiind și ora de religie, nu pot să fie împărțite în „progresiste” și „conservatoriste”, „nici nu este îngăduită desfășurarea oricărui plebiscit atipic de atitudini în spatele disciplinelor, aşa cum s-a întreprins cu făgăduințele despre scutirea nemotivată de la ora de religie". 
Așadar, Biserica Greciei se opune anulării şi înlocuirii orei de religie cu o oră de , «geografie a religiilor» sau de «enciclopedism religios», cu o anumită prezentare, pur și simplu, a Ortodoxiei în spațiul grecesc", tocmai pentru că se contravine, pe de o parte, legislației grecești în vigoare (sunt citate art. 16, alin. 2 din Constituția greacă; art. 1 din Legea 1566/1985; paragraful 1.2. $\gamma^{\prime}$ din Legea 4186/2013), iar pe de altă parte, realității unei țări cu o puternică majoritate a creștinilor ortodocși, cu un anumit capital de cultură și istorie religioasă concretă. În consecință, Sfântul Sinod și-a însușit propunerea mitropolitului Ierotei ca „hotărâre”, pe care a transmis-o Ministerului Educației, Cercetării și Cultelor, și anume:

\begin{abstract}
„interesul să se concentreze asupra Programei de Studii în vigoare, cu propria ei metodologie tematică, la care să se facă, totuși, câteva îmbunătăţiri, integrându-o în datele educaționale contemporane; drept urmare, să fie introduse în fiecare manual, nu la fiecare lecție, câteva capitole de istoria religiilor, în analogie cu tematica manualului, după ce, însă, s-a dat întâietate tradiției ortodoxe, pe care o urmează majoritatea cetățenilor greci, dar și să fie folosite ca aplicații și elementele bune ale Noii Programe de Studii, 32 .
\end{abstract}

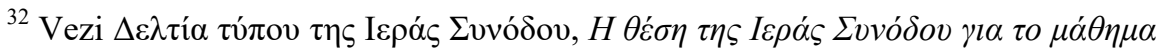

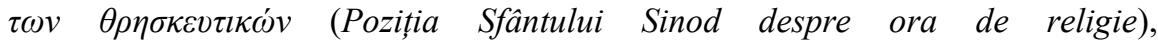
http://www.ecclesia.gr/greek/holysynod/holysynod.asp?id=2080\&what_sub=d_ty pou (accesat 15.04.2016); pentru întregul document adoptat de către Sfầntul Sinod

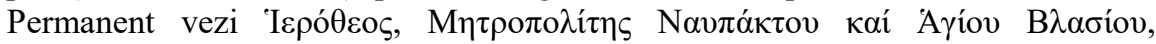

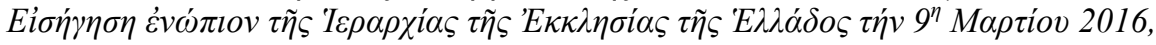

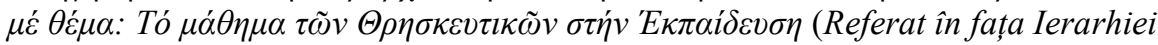
Bisericii Greciei, la 9 martie 2016, cu tema: Ora de religie în Educație), p. 19-22, http://parembasis.gr/images/anakoinoseis/2016/NI_ME_IERARXIA_MAR_2016. pdf (accesat 16.04.2016); Ibidem, http://www.ecclesia.gr/greek/holysynod/nafpaktou_thriskeftika_2016.pdf (accesat

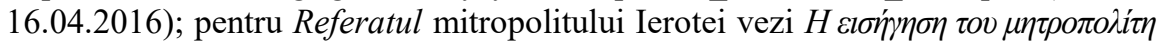

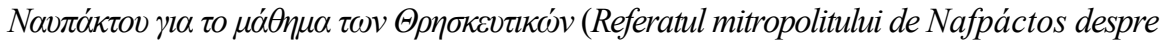

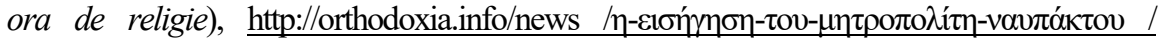
(accesat 16.04.2016); De menționat că Noua Programă de Studii a fost lansată, ca Program pilot, în anul 2011 (revizuită în anul 2014), pentru Şcoala primară și Gimnaziu, iar în 2015 pentru Liceu. Propunerea Sfântului Sinod din Grecia este ca 
La 14 ianuarie 2016, ministrul Educației, Cercetării și Cultelor a primit de la delegația Sfântului Sinod Permanent al Bisericii Greciei documentul de mai sus, considerat că exprima poziția Sfântului Sinod al Bisericii Greciei despre ora de religie. În consecință de cauză, Ministerul a declanşat procedurile privind actualizarea orei de religie, prin constituirea unei comisii speciale a Institutului de Politică Educațională, având în atenție aspectele pe care le evidențiază Biserică, iar ministrul a asigurat că „,clima culturală și Tradiția Ortodoxiei vor avea, cu siguranță, un loc central la ora de religie, care se va lărgi în legătură și referință cu celelalte religii mondiale și cu fenomenul religios în general" ${ }^{3}$.

Promisiunile politicienilor sunt însoțite, adesea, de alte demersuri opuse, aşa cum se constată și în cazul ministrului actual al Educaţiei din Grecia, Nicolae Fílis ${ }^{34}$, care, în același timp, susține, contrar celor afirmate mai sus, anularea caracterului confesional al orei de religie şi

să se menţină Programa Analatică de Studii în vigoare, formulată în anii 2003-

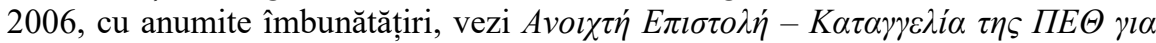

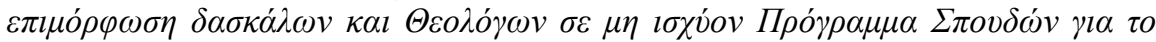

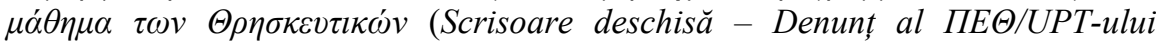
despre formarea învățătorilor și a teologilor în Programa de Studii neaflată în uz pentru ora de religie), http://www.petheol.gr/nea/anoichteepistolekatangeliatespethgiaepimorphosedaskalonkaitheologonsemeischyonprogrammasp oudongiatomathematonthreskeutikon (accesat 16.04.2016).

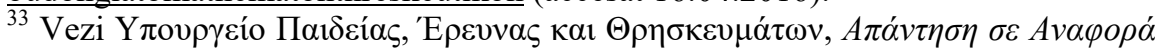

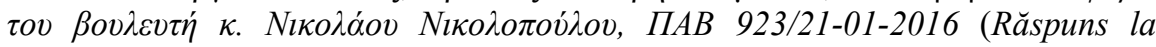
Petiția deputatului dlui Nicolae Nicolopúlu, ПAB 923/21-01-2016), http://www.hellenicparliament.gr/UserFiles/67715b2c-ec81-4f0c-ad6a476a34d732bd/9482323.pdf (accesat 14.04.2016); ibidem, https://www.minedu.gov.gr/grafeio-typoy-kai-dimosion-sxeseon/deltiatypoy/17294-14-01-16 (accesat 16.04.2016).

34 Despre acest ministru se afirmă că a fost neocor și psalt în biserică, vezi

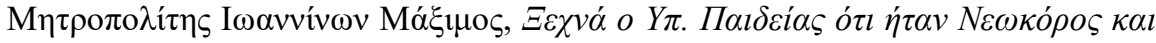
$\Psi \alpha \dot{\lambda} \tau \eta \varsigma$ (Uită ministrul Educației că a fost neocor şi psalt), http://www.romfea.gr/epikairotita-xronika/7188-ioanninon-majimos-jexna-o-uppaideias-oti-itan-neokoros-kai-psaltis (accesat 25.03.2016). 
transformarea ei într-o oră de istorie a religiilor ${ }^{35}$. Aceste declarații au declanşat noi dezbateri, care l-au determinat pe mitropolitul Ierotei de Nafpáctos și Sfântul Vlasie să intervină printr-un nou Referat

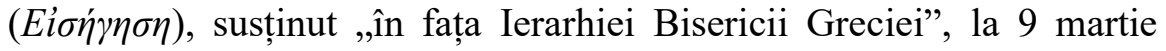
2016, cu tema Ora de religie în Educație, în cadrul întrunirii Sfântului Sinod Plenar al Bisericii Greciei, în perioada 8-10 martie $2016^{36}$. Consider de cuviință ca în continuarea studiului să prezint conținutul acestui Referat, care rezumă, de altfel, întreaga problematică despre ora de religie în Grecia până în acest moment.

Așadar, Referatul, cuprinzând 23 de pagini $^{37}$, se împarte în patru capitole. În primul capitol, intitulat Ședința comună dintre Sfântul

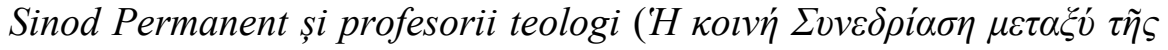

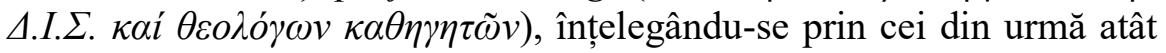
profesorii de religie, cât și cadrele universitare, mitropolitul Ierotei rezumă, într-o primă parte, conținutul Referatului prezentat la 12 ianuarie 2016, precizând că acesta avea patru unități. Mitropolitul Ierotei trece în evidență doar primele două unități, pentru prima

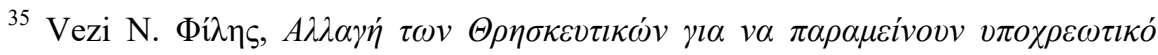
$\mu \alpha ́ \theta \eta \mu \alpha$ (Schimbarea Disciplinei de religie, pentru ca să rămână oră obligatorie), http://www.naftemporiki.gr/story/1078992/n-filis-allagi-ton-thriskeutikon-gia-na-

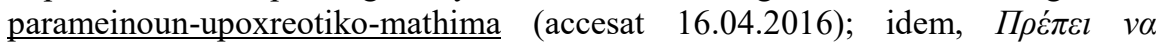

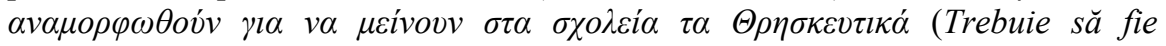
reformulată Disciplina de religie, pentru ca să rămână în școli), http://www.romfea.gr/diafora/6899-filis-prepei-na-anamorfothoun-gia-nameinoun-sta-sxoleia-ta-thriskeutika (accesat 16.04.2016).

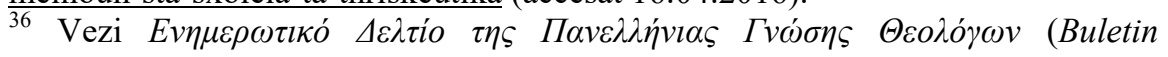
informativ de știri al Uniunii Panelenice a Teologilor), http://www.ipaideia.gr/enimerotiko-deltio-tis-panelinias-enosis-theologon.html (accesat 16.04.2016).

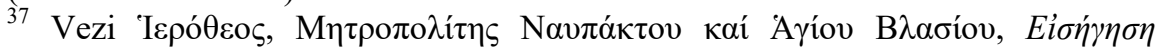

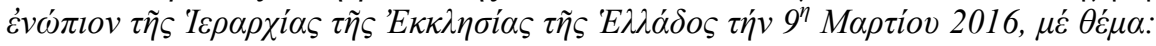

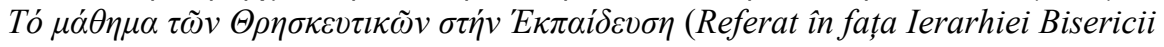
Greciei, la 9 martie 2016, cu tema: Ora de religie în Educație), p. 1-23, http://parembasis.gr/images/anakoinoseis/2016/NI_ME_IERARXIA_MAR_2016. pdf (accesat 16.04.2016); Ibidem, http://www.ecclesia.gr/greek/holysynod/nafpaktou_thriskeftika_2016.pdf (accesat

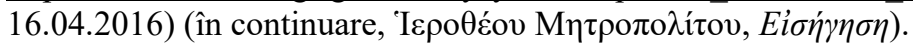


amintind că cuprindea un istoric al discuțiilor purtate asupra orei de religie, cu implicarea directă a Sfântului Sinod, dar care nu a luat vreo „hotărâre concretă”, de-a lungul timpului, iar pentru cea de a doua indicând faptul că în ea s-a făcut analiza conținutului orei de religie. În continuare, expune câteva puncte importante ale Referatului său din 12 ianuarie 2016, fără să mai indice ordinea firească a celorlalte două unități:

a) conform hotărârilor Consiliului de Stat al Greciei (3356/1995 și 2176/1998) și ale Curţii de Apel din Haniá (115/2012), ora de religie trebuie să contribuie la dezvoltarea conștiinței naționale și religioase, conform Constituției grecești, care „,caracterizează dogma ortodoxă ca «religie dominantă», ceea ce înseamnă că «majoritatea covârșitoare a poporului grec se declară pentru Biserica Ortodoxă»»";

b) hotărârea Curții de Apel din Haniá s-a pronunțat că ora de religie, așa cum se predă după manualele în vigoare, se mișcă în cadrul „pluralismului, al polifoniei și al multiculturalității”, precum şi că „elevii ortodocși nu pot să fie scutiți de la ora de religie”, orice motive ar fi invocate, ci este îngăduit să fie scutiți doar „cei fără religie, cei de alte religii sau eterodocșii";

c) analizează faptul că ora de religie în vigoare nu poate să fie caracterizată ca și catehetică sau confesională, precum şi că noua Programă de Studii propusă este de domeniul istoriei religiei sau că depășește atât caracterul catehetic, cât și pe cel de istoria religiilor; în realitate, disciplina de religie, așa cum se predă elevilor, este „gnoseologică, culturală, cu referință la istoria religiilor”, în timp ce noua Programă este mai mult „,interreligioasă”, iar unii o consideră chiar ,sincretistă”;

d) amintește de analiza făcută în acel Referat a manualelor de religie care se predau actualmente în școlile Învățământului secundar, cât și de analiza cuprinsă în același Referat a noii Programe de Studii din Învățământul primar și secundar, prezentându-se avantajele și dezavantajele celor două Programe, adică ale celei în vigoare și ale celei noi sau pilot;

e) este redat, ca concluzie asumată atunci și de Sfântul Sinod Permanent, citatul de mai sus al hotărârii sinodale din 13 ianuarie 2016, 
însoțit de un alt paragraf în care se arată că propunerea respectivă este conformă hotărârilor Curților Superioare Administrative ale Greciei, dar și politicii europene, fiind din nou precizate cele trei categorii de elevi, enunțate mai sus, care pot avea scutire de la ora de religie, din motive de „conștiinţă religioasă” și cu „obligativitatea, totuși, de a li se preda o altă disciplină ${ }^{\prime \prime 3}$.

În cea de a doua parte a primului capitol, mitropolitul Ierotei se referă la acceptarea Referatului și a propunerii sale de către membrii Sfântului Sinod Permanent şi cei prezenți, dar şi la acceptarea propunerii președintelui $\Pi \Theta \Sigma \mathrm{K}^{39} / \mathrm{ATPT}$, care a descris în termeni favorabili noua Programă de Studii ${ }^{40}$.

Cel de al II-lea capitol poartă titlul sugestiv «Programa

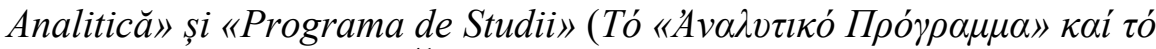

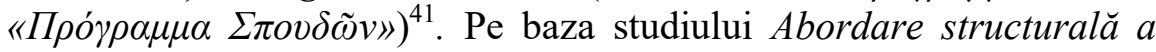
noii Programe de Studii a orei de religie în Școala grecească:

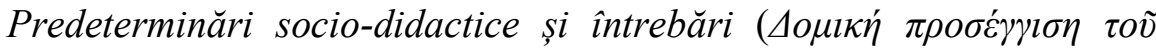

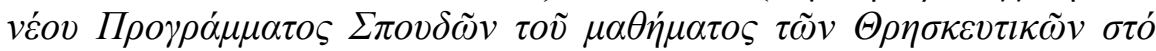

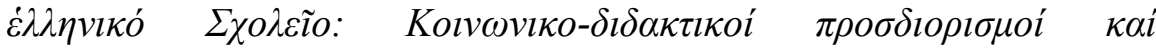

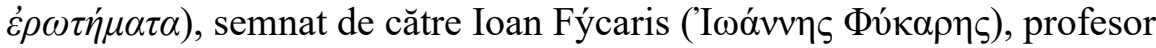
de metodologie didactică la Departamentul Pedagogic de Educație Publică al Universităţii din Ioannina ${ }^{42}$, mitropolitul Ierotei arată diferențele dintre „Programa Analitică” și „Programa de Studii”.

Prin termenul „Programe Analitice”, valabile până acum în Grecia și pe baza cărora au fost redactate manualele după care se predă actualmente, se înțelege „organizarea amănunțită pe bază de plan a unui anumit învățământ, care se bazează pe scopuri de învățare argumentate și clar formulate”. Termenul „Programa de Studii” se referă la o „programă de procedură”, care nu este analitică, ci are un caracter general, cu abordări generale și alegeri din multe nivele. Scopul principal al „Programei de Studii”, bazată pe teoria „regrupării

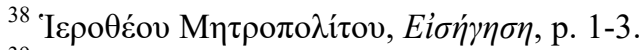

${ }^{39}$ A se citi PTSC.

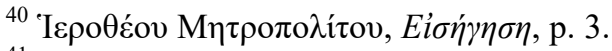

${ }^{41}$ Pentru diferența dintre cele două Programe vezi mai sus nota 30.

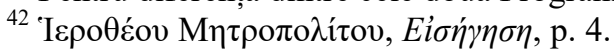


sociale”, este „,̂ndepărtarea aspectelor «nedorite» ale culturii unei societăți și înlocuirea lor cu altele”, considerate „dorite”. Astfel, se urmărește realizarea unei regrupări a culturii, astfel încât elevii să reușească deservirea nevoilor care sunt provocate, promovate sau indicate în fiecare societate de referință. Însă, ,,alt lucru este acceptarea multiculturală și un altul regruparea profilului cultural al unei societăți sau al unui neam".

$\mathrm{Cu}$ alte cuvinte, altceva este ,acceptarea «diferenței», ca un întreg de caracteristici deosebite, care se cuvine să fie luate în seamă de către sistemul educațional şi cadrul didactic", şi un alt lucru este „regruparea deplină a caracteristicilor structurale ale societăţii, în care se dorește integrarea individului, care poartă caracteristici deosebite sociale sau culturale". În virtutea acestor deosebiri, se explică motivul pentru care, avându-se în vedere ora de religie, Institutul de Politică Educațională al Ministerului Educației, Cercetării și Cultelor a trecut de la „Programa Analitică”, valabilă până în anul universitar 2015-2016, la „Programa de Studii”, considerată noutate, și anume, schimbarea viziunii asupra religiei, conform căreia religia „reprezintă o experiență personală și, prin urmare, se propune ca predarea disciplinei să nu fie structurată pe baza Bibliei «obiective» și a dogmelor, ci pe experiențele «subiective» de viață ale elevilor"43.

Mitropolitul Ierotei a cercetat cele două Programe și a ajuns la câteva observații:

1) Manualele de religie, aflate în uz pentru Școala primară și Gimnaziu, au fost redactate conform Programei Analitice elaborate în anul 2003 și au fost introduse în școli în anii 2005-2007. Cu toate acestea, în anii 2010-2011, responsabilii Ministerului Educației au procedat la elaborarea unor noi Programe, care nu sunt „analitice”, ci „tematice”. Acestea au fost aplicate, sub formă de pilot, la 68 de Gimnazii din Grecia, în anii 2011-2014, ceea ce înseamnă că vechea Programă urmează să fie înlocuită cu noua Programă pilot pentru toate Gimnaziile din Grecia. La fel se petrece și cu Școlile primare.

${ }^{43}$ Ibidem, p. 4-5. 
2) Manualele de religie pentru Licee au fost redactate în anul 1999, dar în anul 2015 a fost elaborată o nouă Programă de Studii pentru Licee, care nu a fost încă aplicată sub formă de pilot la un anumit număr de Licee, necunoscându-se în prezent planul Ministerului, altfel spus, dacă se va aplica mai întâi ca pilot, iar apoi se va ajunge la generalizarea ei la toate Liceele din Grecia. Cert este că Programa Analitică în uz nu a fost respinsă ca fiind necorespunzătoare, în timp ce pentru noile Programe de Studii, elaborate pentru toate disciplinele, așadar, și pentru ora de religie, în cadrul acțiunilor privind „Noua Şcoală (Școala secolului al XXI-lea), este prevăzută suma de 113.919.001,06 euro, fiind incluse cele trei stadii, pilot-aplicaregeneralizare ${ }^{44}$.

Pe lângă aceste observații, mitropolitul Ierotei consemnează și „câteva” surprize. Prima dintre ele este că Programa Analitică în uz, cât privește ora de religie, nu este

„confesional-catehetică, după cum pretind unii, ci este gnoseologică, culturală, cu o perspectivă de istoria religiilor. Concret, tematica manualelor de religie este următoarea: clasa I de Gimnaziu: «Vechiul Testament, preistoria Creștinismului»; clasa a II-a de Gimnaziu: «Noul Testament, Iisus Hristos şi lucrarea Lui»; clasa a III-a de Gimnaziu: «Teme din istoria Bisericii»; clasa I de Liceu General: «Credința și cultul ortodox»; clasa a II-a de Liceu General: "Creștinismul și Religiile»; clasa a III-a de Liceu General: «Teme de morală creștină»»"45

De altfel, și Institutul de Politică Educațională recunoștea pentru ora de religie și Programa Analitică corespunzătoare aflată în uz, elaborată conform reformei educaționale din anul 2003, că

„scopul și țelul noilor Programe Analitice”, adică referindu-se la anul 2003, ,se prezintă destul de actualizate, din moment ce evidenţiază contribuția Creștinismului la coeziunea lumii contemporane şi la calitatea vieții umane; urmăresc sensibilizarea și obligația reală a elevilor față de problematizările sociale contemporane; subliniază

\footnotetext{
${ }^{44}$ Ibidem, p. 5-6.

${ }^{45}$ Ibidem, p. 6.
} 
caracterul suprarasial, supraetnic și ecumenic al mesajului creștin, constatările în jurul structurii multiculturale, multirasiale și multireligioase a societăților contemporane și, în fine, ajung la conștientizarea nevoii de comunicare intercreștină și interreligioasă. Disciplina de religie se îndepărtează de caracterul său catehetic și se transformă într-o disciplină care, deși este concentrată pe tradiția ortodoxă, are un clar caracter gnoseologic, formativ și pedagogic... În aceste manuale didactice (pentru Școala primară și Gimnaziu, care au fost scrise din anul 2003 și până în anul 2006), materia religioasă este abordată cu un duh de dialog, libertate și împăcare, fără insistență confesională, catehizare, fanatism sau intoleranță’,46.

Cea de a doua surpriză este faptul că „Noua Programă nu este de istoria religiilor”, ci ,interreligioasă, inspirată de religiozitatea sincretică, în timp ce alții o caracterizează ca fiind sincretistă, iar de către autorii ei este considerată, prin excelență, de trăire"47.

Deși noua Programă are anumite aspecte pozitive, cu toate acestea, ele sunt anulate, deoarece în aceeași lecție „sunt amestecate, concomitent, păreri din alte religii și acest lucru produce confuzie". În plus, nu sunt prevăzute manuale, ci un vast material din care să aleagă profesorul de religie ${ }^{48}$.

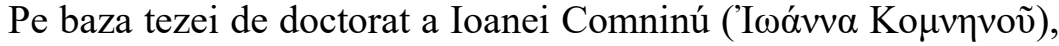
cu titlul Dimensiunea europeană a educației religioase școlare ('H $\varepsilon \dot{v} \rho \omega \pi \alpha \ddot{i} \kappa \dot{\eta} \delta i \alpha ́ \sigma \tau \alpha \sigma \eta \tau \tilde{\eta} \varsigma \sigma \chi 0 \lambda \imath \kappa \tilde{\eta} \varsigma \theta \rho \eta \sigma \kappa \varepsilon v \tau \imath \kappa \tilde{\eta} \varsigma \dot{\alpha} \gamma \omega \gamma \tilde{\eta} \varsigma)^{49}$, mitropolitul Ierotei menționează cele trei modele de predare a disciplinei de religie în școlile din Europa:

1) „modelul confesional”, caracterizat ca predarea religiei astfel încât să fie pusă în legătură predarea cu credința uneia sau mai multor religii; este un model care formează identitatea personală a omului, dar nu distinge diferența dintre disciplina școlară și cateheză, după cum se face într-o societate multiculturală;

\footnotetext{
${ }^{46}$ Ibidem, p. 7.

${ }^{47}$ Ibidem.

${ }^{48}$ Ibidem, p. 8.

${ }^{49}$ Ibidem.
} 
2) „modelul de istoria religiilor”, caracterizat ca ,învățând pentru religie"; este vorba mai mult despre o disciplină umanistă și de istorie a religiilor decât de una confesională, iar elevii sunt ajutați „să perceapă societatea contemporană pluralistă, interculturală și multireligioasă";

3) „modelul multicultural-etic”, caracterizat ca ,învățând de la religie”; conform acestui model, elevii „nu învață o religie (model confesional) sau multe religii (model de istoria religiilor), ci prin propriile lor experiențe și căutări întâmpină critic fenomenul religios și își formulează părerea și percepția lor personală despre lume"50.

Se constată, așadar, că manualele folosite în Învățământul secundar și primar din Grecia combină primele două modele, în timp ce noua Programă de Studii pentru Școala primară, Gimnaziu și Liceu se raportează la cel de al III-lea model. Însă, acest model este criticat deja în Europa și, mai ales, în Marea Britanie, deoarece creează, printre altele, „confuzie elevului”, o „viziune încețoşată” și o „religie individuală”, „unde fiecare alege din orice religie ceea ce dorește şi își face propria sa religie". De altfel, această mentalitate tinde să devină un lucru obișnuit, după Hans Küng, în care mentalitate „religia” este folosită în conformitate cu legea pieții sau, mai degrabă, cu legea supermarket-ului ${ }^{51}$.

Spre exemplificare, mitropolitul Ierotei citează experienţa unui profesor de religie la Gimnaziu, care a fost instruit în noua Programă de Studii, pe care a aplicat-o, constatând multe neajunsuri, precum:

a) confuzia semantică produsă elevilor, în urma comparației concomitente între multe ideologii, religii și curente filosofice;

b) organizare didactică de sine, în cadrul unei semi-imitări, din moment ce nu există izvoare capabile să ajute cadrele didactice;

c) înlocuirea părerilor știinţifice despre fenomenele religioase $\mathrm{cu}$ trăiri subiective, dobândite într-un cadru al relativismului gnoseologic, în funcție de temele religioase studiate;

\footnotetext{
${ }^{50}$ Ibidem, p. 10.

${ }^{51}$ Ibidem, p. 10-11.
} 
d) anularea oricărei logici istorice în cadrul unei prezentări atrăgătoare a religiei, sărindu-se cu mare ușurință de la o temă la alta şi de la un secol la altul, producându-se o „,confuzie bizară ${ }^{, 52}$.

În plus, mitropolitul Ierotei aduce în discuție, cât privește disciplina religie, Programa de Studii pentru clasa a III-a de Şcoală primară $^{53}$. Astfel, elevii, cu vârstele între 9 și 10 ani, în loc să învețe tradiția țării lor, iar cei emigranți să cunoască tradiția țării care îi găzduiește, ei sunt cu toții dezorientați. Deși la primele trei lecții (timp de două ore fiecare), cu titlul „Trăim împreună”, subliniindu-se subiectul „ceilalți și eu”, sunt folosite istorisiri din Vechiul Testament, ca cele despre Isav și Iacov, Iosif și frații lui, David și Saul, David și Ionatan, precum și din Noul Testament, Parabolele despre Bunul Păstor și Tatăl milostiv, la următoarele trei lecții (de asemenea, fiecare câte două ore), cu titlul „Bucuria sărbătorii”, sunt aduse în discuție sărbătorile creștinilor, alături de sărbătorile marilor religii ale lumii, astfel că elevii sunt raportați, în total, la nouă religii și confesiuni. În același timp, sunt recomandate activități demonstrative, adică să găsească elevii pe Sfinții protectori ai orașelor grecești, icoana Sfinților Trei Ierarhi, dar și simboluri din alte religii, apoi fiecare să aleagă unul dintre aceste simboluri, să-l colereze pe fundalul muzicii corespunzătoare și, în continuare, să-și exprime, în funcție de culorile alese, sentimentele și gândurile ${ }^{54}$.

Același lucru se întâlnește și în cazul clasei I de Gimnaziu. Temele primelor lecții sunt:

a) apariția și organizarea Bisericii;

b) întâlnirea Elenismului cu Creștinismul;

c) atitudinea Bisericii „Creștine” în fața întrebărilor despre viață. După aceste lecții urmează altele cinci (timp de două ore fiecare), având ca teme:

\footnotetext{
${ }^{52}$ Ibidem, p. 11-12.

${ }^{53}$ Reamintesc faptul că în Programa primelor două clase ale Şcolii primare din Grecia nu este cuprinsă, ca atare, ora de religie.

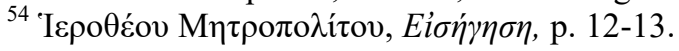


a) religiile monoteiste ale Iudaismului și Islamului, prezentânduse sărbătorile, personajele, conducătorii, precum și faptul că „Allah este «milostiv și îndurător, domnul lumii»»";

b) Jalāl ad-Dīn Muhammad Rūmī ( $\dagger$ 1273), poetul persan al ,,iubirii divine";

c) căutările religioase ale Orientului îndepărtat, adică Hinduismul, Budismul, Taoismul și Confucianismul ${ }^{55}$.

„Aceeași tactică se aplică și la Liceu”, cu diferența că se pune accent pe o metodă ,de trăire”. De pildă, la clasa I de Liceu, într-un grup de lecții numite „Comunicare”, timpul alocat fiind de trei ore, se ascultă ,un cântec sau o poveste sau o istorisire literară cu subiectul despre comunicare, se joacă o piesă de teatru și se analizează subiectul, folosindu-se «rugăciunea, cultul, cunoașterea lui Dumnezeu și teologia ca mijloace de comunicare din Creștinism și din alte tradiții religioase»”, în timp ce elevii ,cercetează diferite aspecte de comunicare cu Dumnezeu și completează întrebări într-o foaie de lucru despre curente mistice (erosul dumnezeiesc etc.), Cântarea Cântărilor, rugăciune, tablouri de pictură, cântec, ascetism (în diferite religii)"'.

În felul acesta, materialul didactic, care trebuie să fie cules de pe Internet, se referă la „monahi budiști, monahismul hinduist, monahi chinezi, asceți ortodocşi, sufi-derviși”, într-un moment al vârstei elevului când „,nu are încă o conștiință deplină a datelor privind atât individualitatea sa, cât și mediul său înconjurător, dar și lumea în general'". În acest caz, rolul Școlii este să lămurească părerile greșite sau confuze pe care fiecare elev le are în gândirea sa, ceea ce indică gradul de responsabilitate pe care trebuie să și-l asume profesorul de religie $^{56}$.

Cel de al III-lea capitol al Referatului este intitulat Alfabetizarea

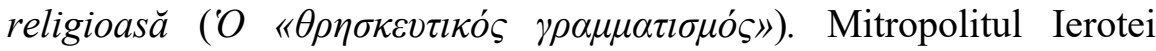
pornește de la afirmația că noua „Programă de Studii a fost concepută şi sprijinită pe principiul fundamental al așa numitei «alfabetizări religioase»”. După ce explică semnificația termenului „alfabetizare”, ca

${ }^{55}$ Ibidem, p. 13.

${ }^{56}$ Ibidem, p. 13-14. 
traducere a termenului englez „literacy” în limba greacă, și anume, $\gamma \rho \alpha \mu \mu \alpha \tau \iota \sigma \mu \varsigma^{57}$, ierarhul grec purcede, pe baza unui studiu al profesorului conferențiar Atanasie Stoiannídis ${ }^{58}$, la identificare conceptului de ,alfabetizare religioasă”.

Astfel, sinodalii au luat la cunoștință că „,alfabetizarea religioasă,, reprezintă o teorie pe care a dezvoltat-o Andrew Wright și se referă la un model multireligios dezvoltat în Marea Britanie, în deceniul anilor '90, ca antipod la viziunea liberală a educației religioase, propusă de Robert Jackson. Așadar, există două teorii despre educația religioasă a elevilor, cea a lui Wright, adică „alfabetizarea religioasă”, și cea a lui Jackson, ,educația religioasă liberală,

După Jackson, „,ea mai înaltă accepțiune liberală a educației religioase este «libertatea individului și toleranța față de ceea ce este diferit, în timp ce convingerile particulare pe care le cultivă tradițiile religioase sunt de o importanță secundară»»". În conformitate cu această concepție, „toate tradițiile religioase au caracteristici comune şi asemănătoare, care exprimă aceeași experiență comună" ${ }^{\prime 60}$.

Wright s-a opus acestei concepții, motivând că modelul lui Jackson , «conduce la sincretism și, în final, la neputința unui dialog fundamental intercultural», deoarece atât libertatea, cât și toleranța față de celălalt «sunt valori care altfel sunt interpretate în Creștinism, diferit în Islam și în alt mod în Budism»”'. În consecință, Wright a dezvoltat modelul „alfabetizării religioase”, care are trei scopuri esențiale sau urmărește dezvoltarea a trei dexterități:

${ }^{57}$ A se citi „grammatismós”.

${ }^{58}$ În Referat se menționează că este profesor conferențiar la Departamentul de Teologie al Facultății de Teologie a Universității Aristotel din Tesalonic, unde predă „Pedagogia Școlară și Metodologia Didactică a Orei de Religie” sau a

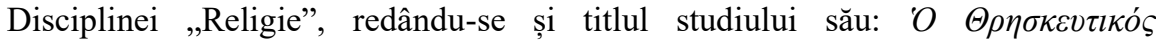

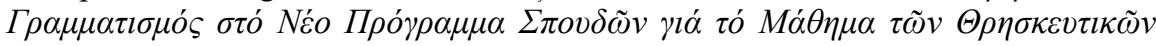

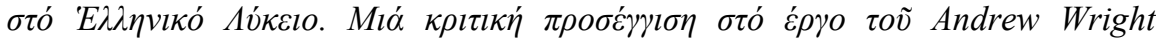
(Alfabetizarea religioasă în Noua Programă de Studii pentru Disciplina de Religie în Liceul Grecesc. O abordare critică lucrării lui Andrew Wright), vezi

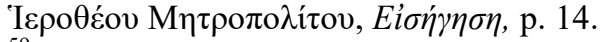

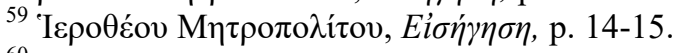

${ }^{60}$ Ibidem, p. 15. 
1) „elevii să conștientizeze şi să formuleze elementele fundamentale ale convingerilor religioase pe care le acceptă";

2) „elevii să prezinte argumentat motivele pentru care aleg conștient să îmbrățişeze una sau o altă convingere religioasă";

3) ,elevii să aleagă, expunând argumente față de diferite convingeri religioase".

„Dacă termenul «alfabetizare» se va traduce cu cuvântul «alfabet», atunci conceptul lui Wright «alfabetizare religioasă» «urmărește să conducă la faptul ca elevii să-şi însușească, în primul rând, alfabetul credinței lor, în al doilea rând, alfabetul despre importanța pe care o are credința în viața lor, în al treilea rând, alfabetul dialogului cu credința celuilalt». Acest lucru înseamnă că elevul, în conformitate cu teoria «alfabetizării religioase», învață «alfabetul» propriei sale credințe, distinge credința ortodoxă de credința celorlalte Confesiuni Creștine, chiar dacă au aceleași principii fundamentale, adică cred în Hristos, precum și faptul că el învață «alfabetul» altor Religii și distinge credința oamenilor care aparțin altor Religii. $\mathrm{Cu}$ alte cuvinte, elevul care primește o educație religioasă conformă cu «alfabetizarea religioasă» nu amestecă «alfabetele» tuturor Religiilor, astfel încât să creeze un «limbaj comun», din moment ce nu se percepe o alfabetizare comună pentru toate Religiile" $" 61$.

Cercetând Introducerile la noua Programă de Studii, în dreptul orelor de religie pentru Liceu, mitropolitul Ierotei constată două aspecte:

1) că autorii noii Programe de Studii nu au urmat metoda «alfabetizării religioase», pe care au anunțat-o ca principiu pentru această Programă, ci au făcut un amestec al celor două concepții diametral opuse, dându-se, totuși, întâietate metodei lui Jackson. Este chiar citat Stephen Prothero, cu cartea sa Religious Literacy, care foloseşte conceptul de «alfabetizare religoasă» în analogie cu „alfabetizarea culturală a lui Hirsch”, dar scopul vădit este ca elevul " «Să cunoască religia celuilalt»", , «să înțeleagă contribuția celorlalți»", adică a celor de alte religii, „«la viața socială»” și „«"să evite greșelile

${ }^{61}$ Ibidem, p. 15-16. 
abordării confesionale și neconfesionale»", altfel spus, se pune accent pe „«concepția liberală a educației religioase», care se află la antipodul «alfabetizării religioase»" ${ }^{\prime 2}$;

2) că manualele de religie în uz, redactate pe baza Programelor Analitice, sunt mult mai apropiate de teoria «alfabetizării religioase», aşa cum a dezvoltat-o Andrew Wright, în timp ce „teoria «liberalismului în educația religioasă» influențează în multe noua Programă de Studii, cu care se face încercarea de a fi găsite punctele comune ale tuturor religiilor și de a fi creată o «credință religioasă particulară», fiind cultivată mai mult o «alfabetizare interreligioasă»»" ${ }^{3}$.

Ultimul capitol al Referatului poartă titlul Hotărârea Sfântului

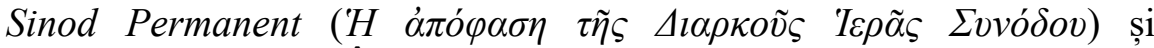
cuprinde trei părți. În prima parte, mitropolitul Ierotei formulează câteva concluzii, cu valoare, totodată, de recomandări:

1) Sfântul Sinod Permanent, în ședințele din 12-13 ianuarie 2016, şi-a exprimat în mod îndreptățit poziția ca Programa Analitică în uz să rămână ca bază de lucru pentru manualele de religie care sunt folosite actualmente în Învățământul național din Grecia.

2) Chiar dacă există o părere bine intenționată, și anume, să se ceară de la stat ca disciplina de religie să dobândească „un caracter confesional-catehetic", acest lucru nu este ușor de realizat datorită mai multor pricini sau cauze:

a) ,niciodată în Grecia ora de religie nu a fost confesionalcatehetică", ${ }^{64}$. În acest punct se cuvine să fac un comentariu. Din perspectiva mentalității greceşti, din moment ce se face o identificare între neam și credință, adică faptul că a fi grec înseamnă a fi ortodox, în acest caz este firesc și de la sine înțeles ca manualele de religie să cuprindă tradiția și credința ortodoxă. Prin urmare, nu se poate accepta acuzația că manualele respective au caracter confesional-catehetic. În baza acestei mentalităţi, mitropolitul Ierotei continuă enumerarea cauzelor:

\footnotetext{
${ }^{62}$ Ibidem, 16-17.

${ }^{63}$ Ibidem, p. 18.

${ }^{64}$ Ibidem.
} 
b) manualele cuprind și referințe la teologia scolastică și cea protestantă;

c) Biserica nu poate să-și încredințeze lucrarea catehetică unor persoane pe care nu le cunoaște și în care nu are încredere;

d) „disciplina [de religie] confesional-catehetică care există în spaţiul european reprezintă un rezultat al conflictelor dintre Confesiunile Creștine și nu are legătură cu teologia ortodoxă,"65.

3) Deși hotărârea Sfântului Sinod Permanent a fost comentată negativ de anumite cercuri conservatoriste, acestea ignoră sau desconsideră faptul că

„Programa Analitică în uz are, într-o mare proporție, elemente de istoria religiilor, are multe aspecte liberale față de subiecte bisericești și că nu poate să fie introdusă în Şcoli ora [de religie] catehetică și confesională, deoarece acest fapt ar avea și alte consecințe, adică vor cere și cei ce aparțin altor religii sau confesiuni să fie introduse manuale confesionale sau vor crește cererile de scutire de la ora de religie" ${ }^{\prime 66}$.

În cea de a doua parte din ultimul capitol al Referatului său, mitropolitul Ierotei redă întregul document formulat de către Sfântul Sinod Permanent, la 13 ianuarie $2016^{67}$, şi depus la Ministerul Educației, Cercetării și Cultelor, în ziua următoare, document pe care 1am prezentat mai sus. În ultima parte a acestui capitol, mitropolitul Ierotei arată care a fost componența delegației din partea Bisericii Ortodoxe a Greciei, care a înmânat respectivul document ministrului Educației, Cercetării și Cultelor, Nicolae Fílis; menționează faptul că a avut loc o discuție largă între membrii delegației și reprezentanții Ministerului, din care reies diferențele de opinii: Sfântul Sinod propune rămânerea la Programa de Studii în uz, cu anumite ajustări, ,astfel încât ora de religie să fie obligatorie pentru toți, cu excepția celor ce doresc să ceară scutire, consemnând, însă, motivele scutirii, în timp ce

\footnotetext{
${ }^{65}$ Ibidem.

${ }^{66}$ Ibidem, p. 19.

${ }^{67}$ Ibidem, p. 19-22.
} 
Ministerul Educației propune să fie aplicată Noua Programă de Studii, la care să fie făcute anumite îmbunătățiri”, ${ }^{\prime 8}$. În consecință, mitropolitul Ierotei propune în atenția întregului Sfântului Sinod documentul citat și redă, pentru încă o dată, hotărârea Sfântului Sinod Permanent din 13 ianuarie, citată și mai sus, ca fiind sinteza diferitelor păreri despre ora de religie ${ }^{69}$.

Celor relatate până în acest punct al studiului se pot adăuga și multe alte documente, evenimente și dezbateri, dar mă voi limita doar la un singur fapt. La 28 februarie 2016, opinia publică din Grecia a luat la cunoștință că i s-a interzis mitropolitului Nicolae de Mesogheia şi Lavreotica, ierarh grec cunoscut și în România pentru așezarea sa duhovnicească şi vasta sa pregătire intelectuală, de a adresa un cuvânt elevilor din două școli ale Tesalonicului, la invitația acestora, în săptămâna ce a precedat respectiva dată ${ }^{70}$, ceea ce a declanșat o mare polemică privind accesul sau nu al clericilor în școlile grecești de stat ${ }^{71}$.

Într-un final, fără ca acest lucru să însemne stingerea tensiunilor create, prim-ministrul guvernului grec Alexe Țipras a adresat o Scrisoare către Arhiepiscopul Atenei și al întregii Grecii, domnului

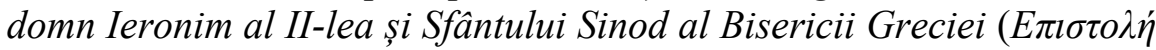

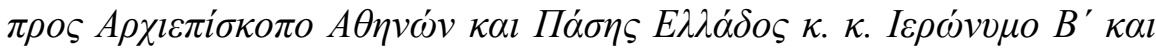

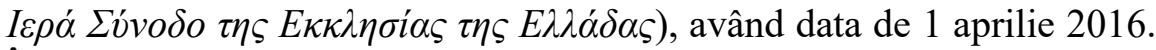
În această Scrisoare, prim-ministrul recunoaște rolul pozitiv al conlucrării dintre Biserică și stat, precizează că dă răspuns Scrisorii pe care Preafericitul Ieronim i-a adresat-o, la 3 martie 2016, în legătură cu vizita preoților în școlile grecești și afirmă că „instituțiile educaționale”

\footnotetext{
${ }^{68}$ Ibidem, p. 23.

${ }^{69}$ Ibidem.
}

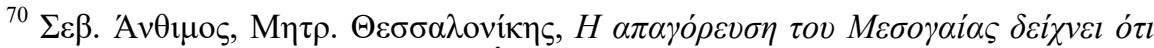

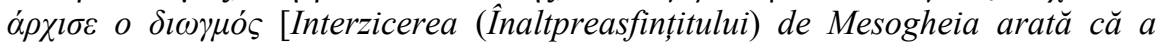
inceput persecuția], http://www.romfea.gr/epikairotita-xronika/6683-anthimos-iapagoreusi-tou-mesogaias-deixnei-oti-arxise-o-diogmos (accesat 28.02.2016).

${ }^{71}$ Până la acest episod, accesul clericilor nu a fost obstrucționat, făcându-se în mod obișnuit, în urma demersurilor legale. Așa se făcea că, adesea, preoții mergeau și îi spovedeau pe elevi direct în școli, ca pregătire pentru participarea la Dumnezeiasca Liturghie. 
ale Greciei „au fost și vor fi întotdeauna deschise reprezentanților Bisericii Greciei”, desigur, în cadrul și procedura reglementate prin lege $\mathrm{e}^{72}$.

\section{Patronii spirituali ai Învățământului și Literelor din Grecia}

De precizat că Sfinţii Trei Ierarhi Vasile cel Mare, Grigorie Teologul şi Ioan Gură de Aur sunt patronii Literelor și ai Învăţământului din Grecia $^{73}$, pentru toate Ciclurile de Educaţie, cu precădere pentru Facultăţile de Teologie şi Instituţiile de învăţământ ale Bisericii, iar cinstirea sărbătorii lor, din 30 ianuarie, este respectată la nivelul întregii țări, reglementată prin lege.

Dacă Ministerul Educaţiei, Cercetării şi Cultelor venea cu precizări asupra cinstirii acestei sărbători, prin Circulara 95567/Г2/20.06.2014, conform căreia ,ziua de 30 ianuarie $2015 \mathrm{nu}$ reprezintă o zi nelucrătoare, ci este considerată o zi de sărbătoare, în timpul căreia se merge la biserică şi se fac activităţi referitoare la aportul pe care Sfinţii Trei Ierarhi 1-au adus Literelor" "74, în schimb, pentru anul universitar 2015-2016, dispoziția aceluiași Minister, dar sub un alt ministru, a fost, prin Circulara $\Phi 1 / 10747 / \Delta 2 / 22.01 .2016$ adresată Gimnaziilor şi Liceelor Generale şi Profesionale, că „unitățile școlare pot să realizeze manifestări de sărbătoare, vineri, 29 ianuarie 2016, consacrând două ore didactice, cu responsabilitatea Directorului

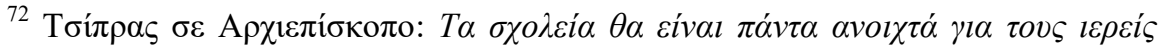
(Țipra către Arhiepiscop: Școlile vor fi mereu deschise pentru preoți), http://www.romfea.gr/epikairotita-xronika/7571-tsipras-se-arxiepiskopo-tasxoleia-tha-einai-panta-anoixta-gia-tous-iereis (accesat 16.04.2016).

${ }^{73}$ Se constată că încă din timpul dominației otomane, poate chiar și mai înainte, sărbătoarea Sfinților Trei Ierarhi a fost considerată și sărbătoare a Educației, în lumea ortodoxă greacă. De aceea, pe baza acestei vechi tradiţii, Senatul Universității Kapodistriene din Atena a decis, în 1841, ca sărbătoarea Sfinților Trei Ierarhi să fie și sărbătoarea Învățământului grecesc şi a Literelor, fapt recunoscut și legalizat apoi de statul grec.

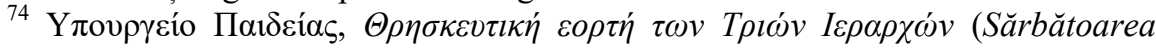
religioasă a celor Trei Ierarhi), http://www.petheol.gr/nea/ekpaideutikanea/ypourgeiopaideiasthreskeutikeeortetontrionierarchon (accesat 08.05.2015). 
și a Consiliului Cadrelor Didactice și după aprecierea lor”, avându-se în vedere faptul că „sărbătoarea Sfinților Trei Ierarhi coincide cu ziua în care nu funcționează școlile (sâmbătă, 30-1-2016)",75. Cât privește Școlile primare, Ministerul a eliberat o altă Circulară, $\Phi 1 / 47$ / 4495 / $\Delta 1 / 14.01 .2016$, prin care anunța că „sărbătorirea celor Trei Ierarhi” va avea loc în aceste Școli ,în primele două ore ale ajunului sărbătorii (vineri, 29-01-2016)”, după care „va fi continuat programul orelor"76.

Se observă, așadar, că fastul și timpul alocat sărbătoririi Sfinților Trei Ierarhi sunt cu mult reduse în anul școlar curent față de anul școlar anterior, fapt datorat și poziției actualei guvernări a Greciei nu doar față de Biserica Ortodoxă, ci și față de orice religie și confesiune, în general, promovându-se o orientare atee. De altfel, această poziție a Ministerului Educației, Cercetării și Cultelor a fost aspru criticată în societatea grecească și văzută ca exprimare a tendinței de a fi redus contactul școlii grecești cu Biserica și credința ortodoxă, din moment ce nu se mai specifică, precum în anii anteriori, participarea la biserică, din contră, dacă pentru Școlile primare reiese că cele două ore consacrate cinstirii Sfinților Trei Ierarhi sunt obligatorii, în schimb, pentru Gimnazii și Licee se poate înțelege că sărbătorirea respectivă este „opțională”, ceea ce ar ascunde, după unele voci, intenția ministrului de a anula sărbătorirea Sfinților Trei Ierarhi ${ }^{77}$.

În ciuda acestei atitudini a guvernului, tradițile consacrate au fost ținute, și anume, participarea elevilor și a cadrelor didactice la Dumnezeiasca Liturghie, precum și a studenților și a profesorilor din

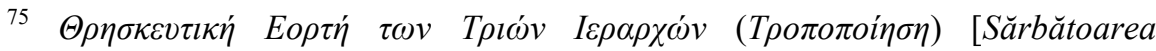
religioasă a celor Trei Ierarhi (Reglementare)], http://edu.klimaka.gr/leitoyrgiasxoleivn/anakoinwseis-leiturgia-scholeiwn/1635-treis-ierarches-giorth.html (accesat 14.04.2016).

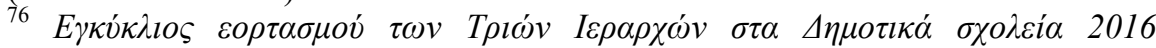
(Circulară de sărbătorire a celor Trei Ierarhi la Școlile primare 2016), http://thriskeftika.blogspot.ro/2016/01/2016.html (accesat 14.04.2016).

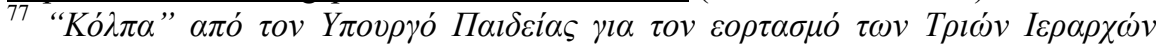
(,,Șiretlicuri” din partea Ministrului Educației pentru sărbătorirea celor Trei Ierarhi), http://www.romfea.gr/epikairotita-xronika/25-diafora/6150-kolpa-apoto-upourgo-paideias-gia-ton-eortasmo-ton-trion-ierarxon (accesat 14.04.2016). 
centrele universitare ale Greciei, eveniment urmat de parastasul „arhieresc” „pentru întemeietorii, donatorii, binefăcătorii, profesorii, studenții și personalul administrativ" ai Universităților din respectivele centre. Cât privește, de pildă, Atena și Universitatea Kapodistriană, după aceste evenimente urmează, în Aula centrală a Universităţii, Discursul oficial al unui profesor de la Facultatea de Teologie din cadrul aceleaşi Universităţi, la care participă reprezentanţii vieţii politice şi culturale greceşti, precum şi reprezentanţii tuturor Facultăţilor din Universitatea respectivă. Șirul evenimentelor s-au desfășurat și în anul școlar curent, chiar în ziua de 30 ianuarie $^{78}$.

Acestor evenimente se adaugă și faptul că la nivel de eparhii, sunt organizate, în după-amiaza zilei de 30 ianuarie, dar şi în zilele următoare, diverse evenimente culturale şi conferințe. De asemenea, Sfântul Sinod al Bisericii Greciei emite, în fiecare an, o Circulară către elevii şi elevele tuturor Școlilor greceşti, dar şi o alta către cadrele didactice ale tuturor ciclurilor de educaţie, care sunt citite în fiecare unitate şcolară din Ciclurile amintite mai sus. Conţinutul Circularei este, de obicei, simplu, dar concis, după cum se poate observa din cea emisă pentru 30 ianuarie $2015^{79}$. Urmând acestei tradiții, pentru anul școlar în curs, Sfântul Sinod a emis, cu ocazia întrunii Sfântului Sinod Permanent la 13 ianuarie 2016, două Circulare, una către cadrele didactice din toate ciclurile, iar o alta către elevii și elevele tuturor Școlilor grecești.

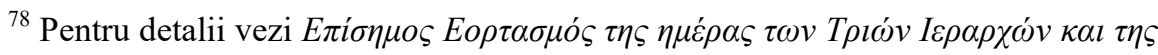

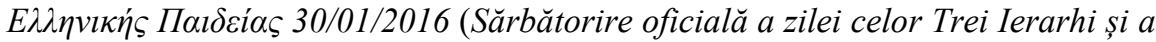
Educației Grecești 30/01/2016), http://www.uoa.gr/anakoinoseis-kaiekdhloseis/ekdhloseis-hmerides-synedria/proboli-ekdilwshs/epishmos-eortasmosths-hmeras-twn-trion-ierarxon-kai-ths-ellhnikis-paideias-30-01-2016.html (accesat 19.04.2016).

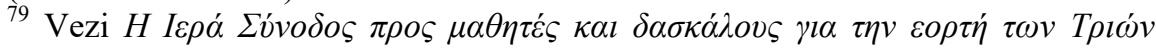

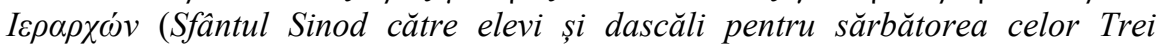
Ierarhi), http://www.petheol.gr/nea/ekpaideutikanea/eierasynodosprosmatheteskaidaskalousgiateneortetontrionierarchon (accesat 08.05.2015). 
În Circulara către cadrele didactice, Sfântul Sinod le aduce aminte acestora că „sărbătorirea Protectorilor Educației”, adică „a Sfinților Trei Ierarhi, reprezintă un excelent prilej de comunicare a Bisericii care păstorește” cu „dascălii și cadrele didactice ale Patriei”, care depun eforturi în educarea elevilor şi a elevelor din școlile grecești. De aceea, Biserica le cinstește „lucrarea și misiunea”, rugându-se zilnic pentru ei și familiile lor, astfel încât ei „să trăiască valorile morale bogate ale celor Trei Ierarhi și să le transmită propriilor copii”, adică nu doar celor după trup, dar şi celor din școlile unde predau, iar aceste valori sunt: „sacralitatea vieții, sacralitatea cunoașterii, precum și virtuțile Dragostei și Libertății”, care reprezintă „valori de neînlocuit ale aportului celor Trei Ierarhi și foarte prețioase indicatoare de cale în lucrarea" lor. Condițiile în care au activat Sfinții Trei Ierarhi sunt, oarecum, asemănătoare cu cele din vremurile actuale, adică epocă de criză și de transformări, dar care nu i-au împiedicat să-și înfăptuiască „,sarcina lor cu respect față de Dumnezeu, față de om şi față de responsabilitatea lor personală ${ }^{\prime \prime 0}$.

Chiar dacă în textul Circularei către elevii și elevele tuturor Școlilor grecești sunt reluate unele idei din Circulara către cadrele didactice, accentul cade pe anumite fapte ale Sfinților Trei Ierarhi, care sunt date ca exemple: „să nu uitați că faimoasa Vasiliadă a Marelui Vasile, o cetate întreagă de case de oaspeți, spitale, azile, a fost opera lui autentică, puțin în afara Cezareei, și rămâne în veci dovadă evidentă de lucrare socială”, pe care Biserica o continuă ,de atunci, cu fidelitate și iubire jertfitoare”; „să nu uitați” ,că Sfântul Grigorie, prin înaltul său cuvânt contemplativ, teologic și poetic, a făcut «cu fapta trecerea la vederea lui Dumnezeu»", precum și că „Sfântul Hrisostom, ca preot în Antiohia, întreținea 3.000 de văduve și orfani, iar ca Patriarh de

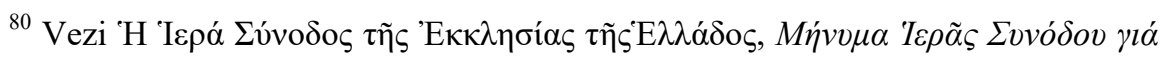

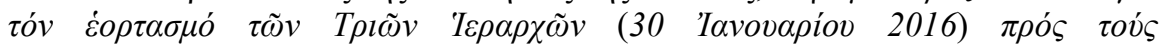

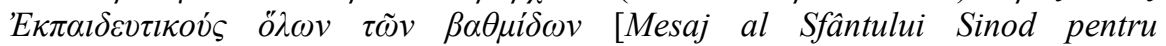
sărbătorirea celor Trei Ierarhi (30 ianuarie 2016) către cadrele didactice din toate ciclurile], p. $2-4$, http://www.ecclesia.gr/greek/holysynod/egyklioi/5_2016.pdf (accesat 14.04.2016). 


\section{$15^{\text {th }}$ International Simposium on Science, Theology and Arts}

Constantinopol hrănea 7.000 de persoane și susținea multe fundații și misiuni filantropice în afara și în interiorul Constantinopolului”"

Prin cercetarea vieții Sfinților Trei Ierarhi, „elevii și elevele” cinstesc „modul minunat de gândire și de trăire al unor oameni liberi și autentici reformatori sociali, care au depus eforturi cu credință în Hristos și cu iubire față de om, pentru care Hristos a murit și a înviat". De asemenea, ei pot lua aminte la modul în care „Sfinții Trei Ierarhi au gustat și au asimilat toate roadele civilizației grecești antice și ale filosofiei, dând evoluției istoriei omului și a umanității frumusețea revelației evanghelice, Cuvântul lui Dumnezeu, cu respect față de cunoaștere și om, cu reușite științifice și sociale, activându-și și crescându-și la maxim toate puterile lor, trăind cu jertfelnicie faptul «iubiți-vă unii pe alții»". În același timp, ei mai pot învăța din felul în care Sfinții Părinți au ajuns la sfințenie, căci aceștia „s-au străduit duhovnicește și au rodit mai bogată lume interioară, prin prezența permanentă a Sfântului Duh în viața lor".

În consecință, îndemnul Bisericii este ca ei să iubească cercetarea, cunoașterea și cultivarea duhovnicească. Ultima nu are ca scop unic „eficacitatea, ci mai ales înfrumusețarea ființei”, iar cunoașterea „este izvor al adevărului, zămislește un mod de trăire și viață, întărește valorile nepieritoare și dă sens vieții” ${ }^{81}$.

\section{Concluzii}

Scopul acestui studiu este multiplu, căci prin el am urmărit să fac cunoscute societății românești dezbaterile și polemicile duse în societatea greacă despre ora de religie, precum și luările de poziție ale Bisericii, prin aportul ierarhiei și al profesorilor de religie, având sprijinul unor numeroși intelectuali și politicieni greci.

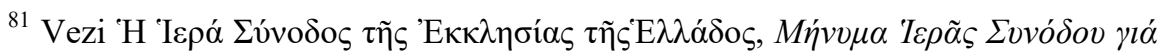

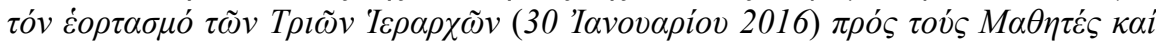

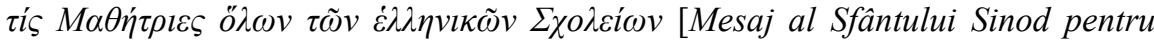
sărbătorirea celor Trei Ierarhi (30 ianuarie 2016) către elevii și elevele tuturor S.colilor], p. 4-6, http://www.ecclesia.gr/greek/holysynod/egyklioi/5_2016.pdf (accesat 14.04.2016). 
Eforturile și luptele depuse pe frontul apărării statutului și conţinutului orei de religie, care oră sau disciplină, aşa cum s-a precizat, face parte din ,trunchiul de bază al disciplinelor de educaţie generală", este obligatorie și are ca materie de bază prezentarea credinţei ortodoxe, ilustrează, printre altele: conștientizarea rolului benefic al educației elevilor în duhul învățăturii ortodoxe; menținerea privilegiului Bisericii Ortodoxe din Grecia de a fi implicată, prin lege, în sistemul educațional de stat, din moment ce Ortodoxia este văzută și primită ca principala expresie a identităţii grecești; lupta de sindicat și apărarea orei de religie și a drepturilor profesorilor de religie sub această formă, ceea ce lipsește din spectrul socio-politic și religios al societății românești; angajarea politicienilor de a sprijini demersurile celor două Asociații sau Corporații ale profesorilor de religie, dar și pozițiile Bisericii; dreptul la dialog, ceea ce înseamnă respectarea libertății de exprimare.

În încheiere, relansez sugestia că nu ar fi de prisos iniţierea organizării unei întâlniri sau a unui simpozion, poate în mai multe ediţii, consacrat orei de religie și a experiențelor dobândite în lumea ortodoxă, prin invitarea celor implicați, spre exemplu, în dezbaterile din Grecia, astfel încât reprezentanții societății românești să ia aminte la felul în care Biserica Ortodoxă şi societatea greacă luptă pentru privilegiile și aportul pozitiv al orei de religie, chiar sub forma de a se acorda în manualele de religie prioritate predării învățăturii creștine ortodoxe.

\section{Bibliografie}

\section{Adrese web}

- http://www.petheol.gr/nea/ekpaideutikaea/neaenkykliostouypourgeioupaideiasgiatisapallagesapotathreskeutika (accesat 08.05.2015)

- $\quad$ http://olme-attik.att.sch.gr/new/wpcontent/uploads/2015/09/apallagesthriskeutika25092015.pdf http://www.petheol.gr/nea/anoikteepistolediamartyriastespanelleniasenos estheologonprostodstesolme (accesat 15.04.2016)

- $\quad$ http://www.kairosnet.gr/joomla/index.php/2010-12-13-21-49-14/73--1r.html (accesat 09.05.2015). 
- $\quad$ http://www.petheol.gr/arthra/to-mathema-tonthreskeutikon/toatomikondikaiomatesthreskeutikeseleutheriastesekklesias nakathorizeeidiatenyletoumtth (accesat 09.05.2015)

- http://www.petheol.gr/nea/ekpaideutikanea/konstantinoscholebasochiallapaichnidiametomathematonthreskeutiko n (accesat 15.04.2016).

- $\quad$ http://www.hellenicparliament.gr/UserFiles/c0d5184d-7550-4265-8e0b078e1bc7375a/9358236.pdf (14.04.2016).

- http://www.hellenicparliament.gr/UserFiles/67715b2c-ec81-4f0c-ad6a476a34d732bd/9391198.pdf (14.04.2016) http://edu.klimaka.gr/leitoyrgia-sxoleivn/dimotiko/726-wrologioprogramma-dhmotiko-scholeio.html (accesat 15.04.2016).

- $\quad$ http://www.petheol.gr.

- $\quad$ http://www.kairosnet.gr.

- $\quad$ http://www.amen.gr/article/theologoi-enantion-theologwn (accesat 09.05.2015).

- $\quad$ http://www.antibaro.gr/article/11379 (accesat 09.05.2015).

- $\quad$ http://www.amen.gr/article/to-mathima-twn-thriskeutikwn-sto-neo-lukeio (accesat 09.05.2015)

- $\quad$ http://www.amen.gr/article/orthodoksi-xristianiki-marturia-kaithriskeutiki-ekpaideusi (accesat 09.05.2015)

- $\quad$ http://www.amen.gr/article/i-peth-gia-to-mathima-twn-thriskeutikwn-kaitin-stasi-tis... (accesat 08.05.2015)

- http://www.amen.gr/article/oloi-mazi-gia-ti-diatirisi-tou-mathimatos-twnthriskeutikwn (accesat 09.05.2015).

http://users.sch.gr/gkapetanak/autosch/joomla15/index.php/11-newsevents/50-ekpaidefsi-i-katixisi (accesat 09.05.2015).

- http://www.ecclesia.gr/greek/holysynod/holysynod.asp?id=2080\&what_s

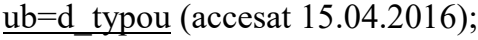

- $\quad$ http://parembasis.gr/images/anakoinoseis/2016/NI_ME_IERARXIA_MA

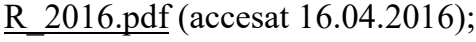

- $\quad$ http://www.ecclesia.gr/greek/holysynod/nafpaktou_thriskeftika_2016.pdf (accesat 16.04.2016);

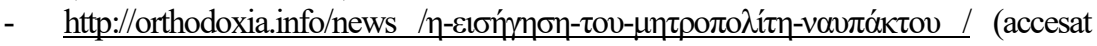
16.04.2016);

- $\quad$ http://www.petheol.gr/nea/anoichteepistole-

katangeliatespethgiaepimorphosedaskalonkaitheologonsemeischyonprogr ammaspoudongiatomathematonthreskeutikon (accesat 16.04.2016).

- $\quad$ http://www.hellenicparliament.gr/UserFiles/67715b2c-ec81-4f0c-ad6a476a34d732bd/9482323.pdf 
https://www.minedu.gov.gr/grafeio-typoy-kai-dimosion-sxeseon/deltiatypoy/17294-14-01-16 (accesat 16.04.2016).

http://www.romfea.gr/epikairotita-xronika/7188-ioanninon-majimosjexna-o-up-paideias-oti-itan-neokoros-kai-psaltis (accesat 25.03.2016).

- $\quad$ http://www.naftemporiki.gr/story/1078992/n-filis-allagi-tonthriskeutikon-gia-na-parameinoun-upoxreotiko-mathima 16.04.2016);

(accesat

- $\quad$ http://www.romfea.gr/diafora/6899-filis-prepei-na-anamorfothoun-giana-meinoun-sta-sxoleia-ta-thriskeutika (accesat 16.04.2016).

- http://www.ipaideia.gr/enimerotiko-deltio-tis-panelinias-enosistheologon.html (accesat 16.04.2016).

- http://parembasis.gr/images/anakoinoseis/2016/NI_ME_IERARXIA_MA R_2016.pdf (accesat 16.04.2016); http://www.ecclesia.gr/greek/holysynod/nafpaktou_thriskeftika_2016.pdf (accesat 16.04.2016)

- http://www.romfea.gr/epikairotita-xronika/6683-anthimos-i-apagoreusitou-mesogaias-deixnei-oti-arxise-o-diogmos (accesat 28.02.2016).

- http://www.romfea.gr/epikairotita-xronika/7571-tsipras-se-arxiepiskopota-sxoleia-tha-einai-panta-anoixta-gia-tous-iereis (accesat 16.04.2016).

- http://www.petheol.gr/nea/ekpaideutikanea/ypourgeiopaideiasthreskeutikeeortetontrionierarchon $\quad$ (accesat 08.05.2015).

- $\quad$ http://edu.klimaka.gr/leitoyrgia-sxoleivn/anakoinwseis-leiturgiascholeiwn/1635-treis-ierarches-giorth.html (accesat 14.04.2016).

- http://thriskeftika.blogspot.ro/2016/01/2016.html (accesat 14.04.2016).

- http://www.romfea.gr/epikairotita-xronika/25-diafora/6150-kolpa-apo-toupourgo-paideias-gia-ton-eortasmo-ton-trion-ierarxon (accesat 14.04.2016).

- $\quad$ http://www.uoa.gr/anakoinoseis-kai-ekdhloseis/ekdhloseis-hmeridessynedria/proboli-ekdilwshs/epishmos-eortasmos-ths-hmeras-twn-trionierarxon-kai-ths-ellhnikis-paideias-30-01-2016.html $\quad$ (accesat 19.04.2016).

- http://www.petheol.gr/nea/ekpaideutikanea/eierasynodosprosmatheteskaidaskalousgiateneortetontrionierarchon (accesat 08.05.2015).

- $\quad$ http://www.ecclesia.gr/greek/holysynod/egyklioi/5_2016.pdf (accesat 14.04.2016).

- http://www.ecclesia.gr/greek/holysynod/egyklioi/5_2016.pdf (accesat 14.04.2016). 